\title{
Marine Sulfated Polysaccharides as Promising Antiviral Agents: A Comprehensive Report and Modeling Study Focusing on SARS CoV-2
}

\author{
Abdalla E. M. Salih ${ }^{1}$, Bathini Thissera ${ }^{1}\left(\mathbb{D}\right.$, Mohammed Yaseen ${ }^{1} \mathbb{D}$, Ahmed S. I. Hassane ${ }^{1,2}$, \\ Hesham R. El-Seedi ${ }^{3,4,5}$, Ahmed M. Sayed ${ }^{6, *(D)}$ and Mostafa E. Rateb ${ }^{1, * \mathbb{D}}$ \\ 1 School of Computing, Engineering \& Physical Sciences, University of the West of Scotland, \\ Paisley PA1 2BE, UK; b00382049@studentmail.uws.ac.uk (A.E.M.S.); Bathini.Thissera@uws.ac.uk (B.T.); \\ Mohammed.Yaseen@uws.ac.uk (M.Y.); ahmedsayed.hassane@nhs.scot (A.S.I.H.) \\ 2 Aberdeen Royal Infirmary, Foresterhill Health Campus, Aberdeen AB25 2ZN, UK \\ 3 Pharmacognosy Group, Department of Pharmaceutical Biosciences, BMC, Uppsala University, Uppsala, \\ Box 591, SE 75124 Uppsala, Sweden; hesham.el-seedi@farmbio.uu.se \\ 4 International Research Center for Food Nutrition and Safety, Jiangsu University, Zhenjiang 212013, China \\ 5 Department of Chemistry, Faculty of Science, Menoufia University, Shebin El-Kom 32512, Egypt \\ 6 Department of Pharmacognosy, Faculty of Pharmacy, Nahda University, Beni-Suef 62513, Egypt \\ * Correspondence: Ahmed.mohamed.sayed@nub.edu.eg (A.M.S.); Mostafa.Rateb@uws.ac.uk (M.E.R.)
}

\section{check for} updates

Citation: Salih, A.E.M.; Thissera, B.; Yaseen, M.; Hassane, A.S.I.; El-Seedi, H.R.; Sayed, A.M.; Rateb, M.E. Marine Sulfated Polysaccharides as Promising Antiviral Agents: A Comprehensive Report and Modeling Study Focusing on SARS CoV-2. Mar. Drugs 2021, 19, 406. https://doi.org/ $10.3390 /$ md19080406

Academic Editors: Khaled A. Shaaban and Vassilios Roussis

Received: 31 May 2021

Accepted: 20 July 2021

Published: 22 July 2021

Publisher's Note: MDPI stays neutral with regard to jurisdictional claims in published maps and institutional affiliations.

Copyright: (c) 2021 by the authors Licensee MDPI, Basel, Switzerland. This article is an open access article distributed under the terms and conditions of the Creative Commons Attribution (CC BY) license (https:/ / creativecommons.org/licenses/by/ $4.0 /)$.
Abstract: SARS-CoV-2 (severe acute respiratory syndrome coronavirus-2) is a novel coronavirus strain that emerged at the end of 2019, causing millions of deaths so far. Despite enormous efforts being made through various drug discovery campaigns, there is still a desperate need for treatments with high efficacy and selectivity. Recently, marine sulfated polysaccharides (MSPs) have earned significant attention and are widely examined against many viral infections. This article attempted to produce a comprehensive report about MSPs from different marine sources alongside their antiviral effects against various viral species covering the last 25 years of research articles. Additionally, these reported MSPs were subjected to molecular docking and dynamic simulation experiments to ascertain potential interactions with both the receptor-binding domain (RBD) of SARS CoV-2's spike protein (S-protein) and human angiotensin-converting enzyme-2 (ACE2). The possible binding sites on both S-protein's RBD and ACE2 were determined based on how they bind to heparin, which has been reported to exhibit significant antiviral activity against SARS CoV-2 through binding to RBD, preventing the virus from affecting ACE2. Moreover, our modeling results illustrate that heparin can also bind to and block ACE2, acting as a competitor and protective agent against SARS CoV-2 infection. Nine of the investigated MSPs candidates exhibited promising results, taking into consideration the newly emerged SARS CoV-2 variants, of which five were not previously reported to exert antiviral activity against SARS CoV-2, including sulfated galactofucan (1), sulfated polymannuroguluronate (SPMG) (2), sulfated mannan (3), sulfated heterorhamnan (8), and chondroitin sulfate E (CS-E) (9). These results shed light on the importance of sulfated polysaccharides as potential SARS-CoV2 inhibitors.

Keywords: sulfated polysaccharides; antiviral; SARS-CoV-2; docking; molecular dynamic simulations

\section{Introduction}

Mother Nature remains an outstanding hub for valuable natural compounds that have been used for multiple purposes since ancient times by our ancestors, including pharmaceutical, biomedical, nutritional, and cosmetics applications. Among the dozens of natural product groups, polysaccharides are macromolecular polymeric carbohydrate molecules comprised of large chains of monosaccharide units. They are widely found in animals, plants, and microorganisms, and their functions are mainly either structureor storage-related. Many studies have revealed that natural polysaccharides and their 
chemically modified derivatives have significant inhibitory activities against viral diseases such as human immunodeficiency virus (HIV) and herpes simplex virus (HSV) [1,2].

Sulfated polysaccharides (SPs) are a class of negatively charged polysaccharides comprising natural or modified sulfate moieties in their structural carbohydrate backbone. They possess significant biological activities such as antioxidant, anti-allergic, antiviral, anticancer, and anticoagulant abilities; hence, the study of SPs has significant importance for drug discovery campaigns [1,3]. SPs are mainly found in the cell walls of marine algae or seaweeds; they are less common in some mammals, such as fish skins, and rare in mangrove plants. The seaweed cell wall comprises about $40 \%$ of sulfated polysaccharides, which is relatively higher than the average content in other sources. The most interesting marine algal SPs are sourced from ulvans from green macroalgae, carrageenans and agar from red macroalgae, and fucoidans and laminarians from brown macroalgae. These SPs have shown antiviral activity against herpes simplex virus (HSV), human immunodeficiency virus type1 (HIV-1), chikungunya virus, cytomegalovirus (CMV), influenza virus, and hepatitis virus, in addition to other enveloped and non-enveloped viruses. Moreover, the antiviral activity of SPs against the current COVID-19 pandemic has also been reported $[1,4,5]$.

Marine sulfated polysaccharides (MSPs) have recently received increasing attention due to their antiviral activity. In particular, carrageenans have exhibited promising inhibitory effects on many viral strains, effectively preventing the internalization of virus particles by interfering with the interactions between the virus and host cell receptors. Carrageenan nasal spray (Boots Dual Defence ${ }^{\circledR}$ in the UK market) has been proven effective in patients with common cold infected by human coronaviruses beta and alpha. In contrast, the impact was attributed to the increased viral clearance and the reduced relapses of symptoms in children and adults [6]. Another nasal spray formulation (xylometazoline $\mathrm{HCl}$ ) containing iota-carrageenan (4) can effectively relieve nasal congestion of the upper respiratory tract and protect the respiratory mucosa against viral infection [7]. Coldamaris ${ }^{\circledR}$ lozenges, comprising iota-carrageenan (4) as the active pharmaceutical ingredient, cause denaturation of glycoproteins on the coronavirus surface, inhibiting the virucidal effects of coronavirus [8].

It remains challenging to develop novel drugs within a limited timeframe, as drug discovery is time- and resource-consuming; however, the process of drug discovery is immensely enhanced by the modern era of computational technology, which has accelerated drug discovery and drug repurposing. Computer-assisted or in silico design employs computational methods in drug discovery and is being applied to streamline and speed up hit-to-lead optimization and hit identification. Several computational techniques have been introduced to predict and select therapeutic targets, study the interactions between drug and receptor, characterize and determine ligand binding sites on the targets, and determine hit compounds using ligand- and structure-based virtual screening $[9,10]$.

Molecular docking and dynamic simulations are the most intriguing among the computational tools employed for structure-based drug discovery, an approach that evaluates the binding affinities between two candidates: small molecules and macromolecular targets (protein). Many drugs currently in the market were developed based on in silico strategies, such as zanamivir (used to treat influenza), nelfinavir, and saquinavir (used in the treatment of HIV); therefore, computational methods have been receiving popularity in the pharmaceutical industry as being crucial in the drug discovery process as reliable and effective techniques [11-13].

In the present investigation, we aimed to shed light on the antiviral potential of MSPs, illustrating their modes of interaction against different targets with the aid of several in silico tools, highlighting the most potential candidates for further investigation against SARS CoV-2.

\section{Results and Discussion}

Herein, we have summarized the findings of approximately 80 research studies published in the last 25 years on MSPs that exhibited potential antiviral effects against a total 
of 22 different viral strains (Table 1, Figure S1). These antiviral MSPs were sourced from various marine sources, including brown algae, red algae, green algae, blue-green algae, microalgae, sea cucumber, and squid cartilage. According to the findings, $40 \%$ of the antiviral MSPs were isolated from the red algae, followed by $24 \%$ from brown algae, $14 \%$ from green algae, $10 \%$ from blue-green algae, $9 \%$ from microalgae, $2 \%$ from squid cartilage, and $1 \%$ from sea cucumber (Figure 1). The red-algae-derived MSPs exhibited greater efficacy against several viruses; however, the distribution was highly skewed towards herpes simplex viruses (HSV), which received most of the research effort (Figure S1).

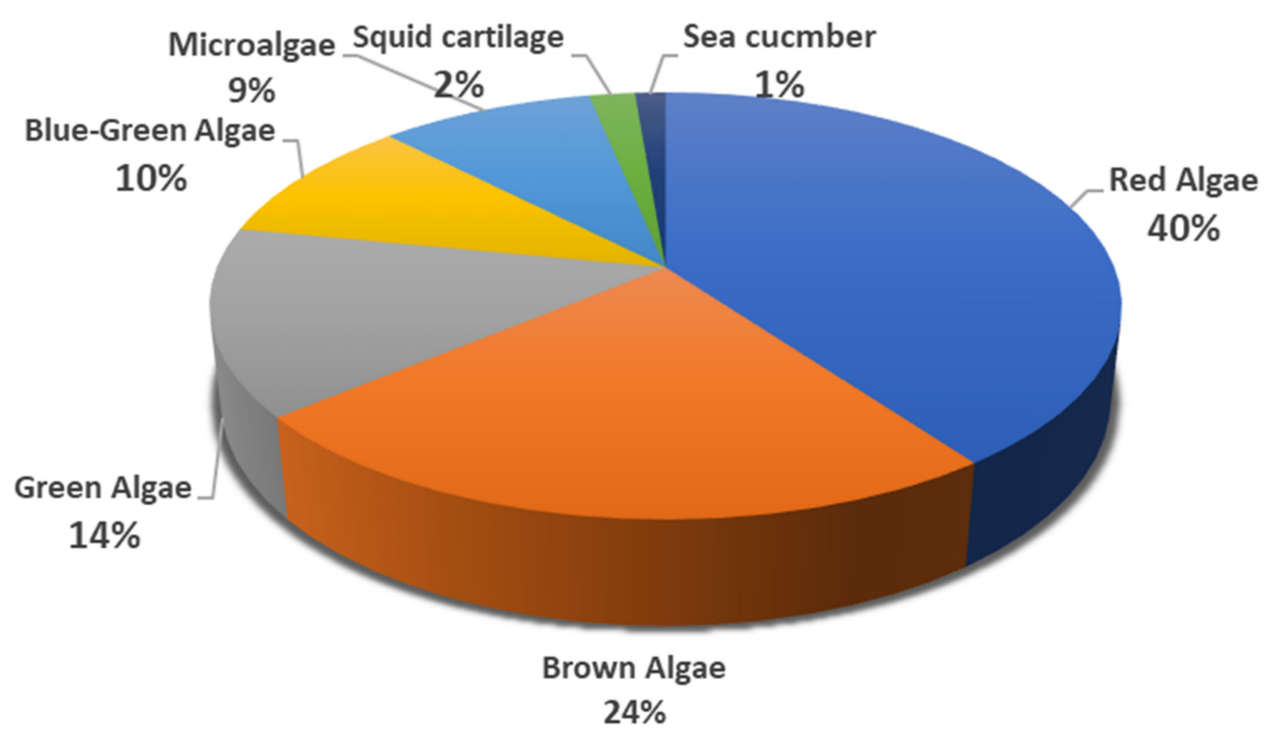

Figure 1. The systematic study of marine sources of MSPs that have shown antiviral activities in the last 25 years.

\subsection{MSPs from Red Algae}

Red macroalgae were commercially considered more valuable than brown and green macroalgae and are widely used in manufacturing hydrocolloids, such as carrageenan and agar, which in turn are involved many applications, such as food, pharmaceutical, and biotechnological industries. The principal polysaccharide components of the red algae are sulfated galactans that are produced extracellularly; however, they are made up of a linear backbone of alternating 3-linked $\beta$-D-galactopyranose and 4-linked $\alpha$-D-galactopyranose, with a few exceptions, such as DL-hybrid sulfated galactan. The various structural types of sulfated galactan (7) have revealed potent antiviral activity against several types of enveloped viruses, such as HSV-1, HSV-2, DENV-2, HIV-1, and HIV-2 (Table 1). 
Table 1. The antiviral activity levels and modes of action of different MSPs derived from various marine sources.

\begin{tabular}{|c|c|c|c|c|c|}
\hline Sources & Compounds & Activity & Efficacy & Mode of Action & References \\
\hline \multicolumn{6}{|c|}{ Brown Algae } \\
\hline Undaria pinnatifid & Sulfated galactofucan & HSV-1, HSV-2, and HCMV & $\mathrm{IC}_{50}=0.2-1.1 \mu \mathrm{g} / \mathrm{mL}$ & Inhibit virus entry and host cell binding & {$[14,15]$} \\
\hline Saccharina japonica & $\begin{array}{l}\text { Fucoidan: RPI-27 and RPI-28 in } \\
\text { a complex }\end{array}$ & SARS-CoV-2 & $\mathrm{EC}_{50}=8.3 \pm 4.6 \mu \mathrm{g} / \mathrm{mL}$ & S-protein binding & [17] \\
\hline Padina boryana & Fucoidan: $\alpha-(1 \rightarrow 3)$-linked & SARS-CoV-2 & $\mathrm{IC}_{50}=15.6 \mu \mathrm{g} / \mathrm{mL}$ & S-protein binding & {$[18,19]$} \\
\hline Laminaria japonica & $\begin{array}{l}\text { Sulfated polymannuroguluronate } \\
\text { (SPMG) }\end{array}$ & HIV-1 & $100 \mu \mathrm{g} / \mathrm{mL}$ & $\begin{array}{l}\text { Inhibit HIV-1 entry by suppressing } \\
\text { rgp120 binding to sCD } 4\end{array}$ & {$[21]$} \\
\hline Laminaria japonica & $\begin{array}{c}\text { Sulfated polymannuronate } \\
\text { (SPMG)-derived oligosaccharides }\end{array}$ & HIV-1 & $\mathrm{ID}_{50}=5.3 \mathrm{nM}$ & $\begin{array}{l}\text { Inhibit HIV-1 entry by suppressing } \\
\text { rgp120 binding to sCD } 4\end{array}$ & {$[22]$} \\
\hline Adenocystis utricularis & Sulfated galactofucan & HSV-1 and HSV-2 & $\mathrm{IC}_{50}=1.25-2.16 \mu \mathrm{g} / \mathrm{mL}$ & Unknown & {$[23,24]$} \\
\hline Stoechospermum marginatum & $\begin{array}{c}\text { Sulfated fucan: }(1 \rightarrow 4) \text { - and } \\
(1 \rightarrow 3) \text {-linked- } \alpha \text {-L-fucopyranosyl } \\
\text { residues }\end{array}$ & HSV-1 and HSV-2 & $\mathrm{EC}_{50}=0.63-10.0 \mu \mathrm{g} / \mathrm{mL}$ & $\begin{array}{l}\text { Inhibit binding of the virus to the host } \\
\text { cell receptor }\end{array}$ & {$[25,26]$} \\
\hline Sargassum horneri & Fucoidan & HSV-1, HIV-1, and HCMV & $\mathrm{IC}_{50}=1-3.3 \mu \mathrm{g} / \mathrm{mL}$ & Unknown & [27] \\
\hline Kjellmaniella crassifolia & Fucoidan KW & Inf $A$ virus (H1N1, H3N2) & $\mathrm{IC}_{50}<6.5 \mu \mathrm{g} / \mathrm{mL}$ & Suppress the replication & {$[28]$} \\
\hline Sargassum patens & Galactofucan & HSV-1 and HSV-2 & $\mathrm{EC}_{50}=1.3-5.5 \mu \mathrm{g} / \mathrm{mL}$ & Inhibit adsorption & [29] \\
\hline Leathesia difformis & Fucoidan & HSV-1, HSV-2, and HCMV & $\mathrm{IC}_{50}=0.5-1.9 \mu \mathrm{g} / \mathrm{mL}$ & Inhibit protein synthesis and adsorption & [30] \\
\hline Fucus evanescens & Fucoidan & HSV-2 & $10 \mathrm{mg} / \mathrm{kg} /$ day for 5 days & Unknown & {$[31]$} \\
\hline Undaria pinnatifida & Fucoidan & HSV-1, HSV-2, and HCMV & $\mathrm{IC}_{50}=1.5-2.6 \mu \mathrm{g} / \mathrm{mL}$ & Inhibit entry and binding & [32] \\
\hline Sphacelaria indica & Xylogalactofucan and alginic acid & HSV-1 & $\mathrm{IC}_{50}=0.6-10 \mu \mathrm{g} / \mathrm{mL}$ & Inhibit adsorption & [33] \\
\hline $\begin{array}{c}\text { Sargassum mcclurei, } \\
\text { Sargassum polycystum, and } \\
\text { Turbinara ornata }\end{array}$ & Fucoidan & HIV-1 & $\mathrm{IC}_{50}=0.33-0.7 \mu \mathrm{g} / \mathrm{mL}$ & Inhibit entry & {$[34]$} \\
\hline Scinaia hatei & Sulfated xylomannan & HSV-1 and HSV-2 & $\mathrm{IC}_{50}=0.5-4.6 \mu \mathrm{g} / \mathrm{mL}$ & Inhibit replication and virus binding & {$[16]$} \\
\hline
\end{tabular}


Table 1. Cont.

\begin{tabular}{|c|c|c|c|c|c|}
\hline Sources & Compounds & Activity & Efficacy & Mode of Action & References \\
\hline Cladosiphon okamuranus & Fucoidan & NDV & $\mathrm{IC}_{50}=0.75 \pm 1.6 \mu \mathrm{g} / \mathrm{mL}$ & Inhibit viral-induced syncytia formation & [35] \\
\hline Cladosiphon okamuranus & Fucoidan & DENV-2 & $\begin{array}{c}\text { Structure-based analysis: } \\
\text { fucoidan interacts directly } \\
\text { with envelope glycoprotein } \\
\text { (EGP) on DEN2 }\end{array}$ & Inhibit binding & {$[36]$} \\
\hline $\begin{array}{l}\text { Undaria pinnatifida- derived } \\
\text { fucoidan (UPF) }\end{array}$ & Fucoidan & InfAV (H1N1, PR8) & $7.0 \mathrm{mg} /$ day for 7 days & & [37] \\
\hline \multicolumn{6}{|c|}{ Red Algae } \\
\hline $\begin{array}{l}\text { Gymnogongrus griffithsiae } \\
\text { and Cryptonemia crenulata }\end{array}$ & $\begin{array}{c}\text { Kappa/iota/nu Carrageenan and } \\
\text { DL-galactan hybrid }\end{array}$ & HSV-1 and HSV-2 & $\mathrm{IC}_{50}=0.5-5.6 \mu \mathrm{g} / \mathrm{mL}$ & Inhibit adsorption & {$[39]$} \\
\hline Sebdenia polydactyla & Sulfated xylomannans & HSV-1 & $\mathrm{IC}_{50}=0.35-2.8 \mu \mathrm{g} / \mathrm{mL}$ & Inhibit virus attachment to the host cell & {$[40]$} \\
\hline Euchema spinosum & Iota-carrageenan & SARS-CoV-2 & $\mathrm{IC}_{50}=2.6 \mu \mathrm{g} / \mathrm{mL}$ & Inhibit replication & {$[41,42]$} \\
\hline Euchema spinosum & $\begin{array}{l}\text { Iota-carrageenan with } \mathrm{Xylitol}^{\circledR} \\
\text { nasal spray }\end{array}$ & SARS-CoV-2 & $\mathrm{IC}_{50}<6.0 \mu \mathrm{g} / \mathrm{mL}$ & Inhibit SARS-CoV-2 in vitro & {$[42,43]$} \\
\hline Chondrus crispus & lambda-carrageenan & $\begin{array}{l}\text { SARS-CoV-2, and InfV A } \\
\text { and B }\end{array}$ & $\mathrm{EC}_{50}=0.3-1.4 \mu \mathrm{g} / \mathrm{mL}$ & Prevent the entry & {$[42,44]$} \\
\hline Euchema spinosum & $\begin{array}{l}\text { Iota-carrageenan containing } \\
\text { Xylometazoline HCL }\end{array}$ & $\begin{array}{l}\text { hRV1a, hRV8, and } \\
\text { hCoV-OC43 }\end{array}$ & $\begin{array}{c}\mathrm{IC}_{50} \text { for hRV1a and } \\
\mathrm{hRV} 8=1.56-6.2 \mu \mathrm{g} / \mathrm{mLMIC} \text { for } \\
\mathrm{hCoV-OC} 43=0.024 \mu \mathrm{g} / \mathrm{mL}\end{array}$ & Prevent the entry & {$[7,42]$} \\
\hline Gigartina skottsbergii & $\kappa / \iota / \mu / \nu$-carrageenan & HIV-1 & $\mathrm{IC}_{50}=0.4-3.3 \mu \mathrm{g} / \mathrm{m}$ & $\begin{array}{l}\text { Prevent binding and replication } \\
\text { of virions }\end{array}$ & {$[45]$} \\
\hline Gymnogongrus torulosus & DL-hybrid sulfated galactan & HSV-1 and HSV-2 & $\mathrm{IC}_{50}=1.1$ to $27.4 \mu \mathrm{g} / \mathrm{mL}$ & Unknown & {$[46,47]$} \\
\hline Cryptonemia crenulata & DL-galactan hybrid C2S-3 & DENV-2 & $\mathrm{IC}_{50}=1 \mu \mathrm{g} / \mathrm{mL}$ & Block virus multiplication & {$[48,49]$} \\
\hline Stenogramme interrupta & $\xi$ - and $\lambda$-carrageenans & HSV-1 and HSV-2 & $\mathrm{IC}_{50}=0.65-2.88 \mu \mathrm{g} / \mathrm{mL}$ & Inhibit binding and replication & {$[50]$} \\
\hline Gracilaria corticata & Sulfated galactan & HSV-1 and HSV-2 & $\mathrm{IC}_{50}=0.19-0.24 \mu \mathrm{g} / \mathrm{mL}$ & Inhibit virus attachment to the host cell & {$[51,52]$} \\
\hline Aghardhiella tenera & Sulfated galactan & HIV-1 and HIV-2 & $\mathrm{IC}_{50}=0.05-0.5 \mu \mathrm{g} / \mathrm{mL}$ & $\begin{array}{c}\text { Inhibit cytopathic effect of HIV-1 and } \\
\text { HIV-2 in MT- } 4 \text { cells }\end{array}$ & {$[53]$} \\
\hline
\end{tabular}


Table 1. Cont.

\begin{tabular}{|c|c|c|c|c|c|}
\hline Sources & Compounds & Activity & Efficacy & Mode of Action & References \\
\hline Nemalion helminthoides & Sulfated mannan & HSV-1 & $\mathrm{IC}_{50}=5.43-9.68 \mu \mathrm{g} / \mathrm{mL}$ & Unknown & {$[54]$} \\
\hline Nothogenia fastigiata & Sulfated xylomannan & HSV-1 and HSV-2 & $\mathrm{IC}_{50}=0.6-1.3 \mu \mathrm{g} / \mathrm{mL}$ & Prevent binding and replication & {$[55,56]$} \\
\hline Nothogenia fastigiata & Sulfated xylogalactans & HSV-1 & $\mathrm{EC}_{50}=15.0-32.6 \mu \mathrm{g} / \mathrm{mL}$ & Inhibit virus attachment to the host cell & {$[58,59]$} \\
\hline $\begin{array}{l}\text { Euchema spinosum } \\
\text { Chondrus crispus }\end{array}$ & Lambda/Iota-carrageenan & DENV-2 and DENV-3 & $\mathrm{EC}_{50}=0.14-4.1 \mu \mathrm{g} / \mathrm{mL}$ & Interference with virus adsorption & {$[42,60]$} \\
\hline Euchema spinosum & $\begin{array}{c}\text { Iota-carrageenan containing lozenges } \\
\left.\text { (Coldamaris }{ }^{\circledR}\right)\end{array}$ & $\begin{array}{l}\text { hRV1a, CoV OC43, and InfA } \\
\text { H1N1n }\end{array}$ & 10 mg daily & Prevent binding and inhibit replication & [8] \\
\hline Euchema spinosum & Iota-carrageenan nasal spray & $\begin{array}{c}\text { hRV1a, CoV OC43, and InfA } \\
\text { H1N1n }\end{array}$ & Total of $1.0 \mathrm{mg}$ daily & $\begin{array}{c}\text { Prevent the virus from binding to cell } \\
\text { surfaces or } \\
\text { penetrating the cells }\end{array}$ & {$[42,61]$} \\
\hline Euchema spinosum & Iota-carrageenan, nasal spray & $\mathrm{H} 1 \mathrm{~N} 1$ and $\mathrm{H} 3 \mathrm{~N} 2$ & $\mathrm{IC}_{50}=0.04-0.2 \mu \mathrm{g} / \mathrm{mL}$ & $\begin{array}{l}\text { Effectively inhibit virus adsorption to } \\
\text { host cells and reduce replication }\end{array}$ & {$[42,62]$} \\
\hline Euchema spinosum & Iota-Carrageenan & $\mathrm{HPV}$ & $\mathrm{IC}_{50}=0.005 \mu \mathrm{g} / \mathrm{mL}$ & $\begin{array}{l}\text { Blocking the initial interaction of capsids } \\
\text { with cells and exert a postattachment } \\
\text { inhibitory effect. }\end{array}$ & [64] \\
\hline Acanthophora specifira & Lambda-carrageenan & HSV-1 and RVFV & $\mathrm{IC}_{50}=75.8-80.5 \mu \mathrm{g} / \mathrm{mL}$ & Inhibit replication & [65] \\
\hline Lithothamnion muelleri & Sulfated xylogalactans & HSV-1 and HSV-2 & $\mathrm{EC}_{50}=49.64-125.79 \mu \mathrm{g} / \mathrm{mL}$ & Inhibit adsorption and penetration & {$[59,66]$} \\
\hline Scinaia hatei & Sulfated xylan & HSV-1 and HSV-2 & $\mathrm{IC}_{50}=0.22-1.37 \mu \mathrm{g} / \mathrm{mL}$ & Inhibit entry & [67] \\
\hline Euchema spinosum & Iota-Carrageenan & SARS-COV-2 & $\mathrm{IC}_{50} \geq 125 \mu \mathrm{g} / \mathrm{mL}$ & Unknown & {$[18,42]$} \\
\hline Sigma (Sigma Aldrich) & Carrageenan & $\begin{array}{l}\text { Japanese encephalitis virus } \\
\text { (JEV) }\end{array}$ & $\mathrm{EC}_{50}=15 \mu \mathrm{g} / \mathrm{mL}$ & $\begin{array}{c}\text { Inhibit attachment and the cellular } \\
\text { entry stages }\end{array}$ & [68] \\
\hline Tichocarpus crinitus & $\kappa / \beta$-carrageenan & Tobacco Mosaic Virus (TMV) & $1 \mathrm{mg} / \mathrm{mL}$ & Significantly inhibit virus replication & [69] \\
\hline Chondrus crispus & Lambda-carrageenan & DENV-2 and DENV-3 & $\begin{array}{l}>99 \% \text { reduction in virus } \\
\text { production at } 20 \mu \mathrm{g} / \mathrm{mL}\end{array}$ & Inhibit entry & {$[42,70]$} \\
\hline
\end{tabular}


Table 1. Cont

\begin{tabular}{|c|c|c|c|c|c|}
\hline Sources & Compounds & Activity & Efficacy & Mode of Action & References \\
\hline \multirow[t]{2}{*}{ Meristiella gelidium } & Iota/kappa/nu-hybrid carrageenan & DENV-2 & $\mathrm{IC}_{50}=0.14-1.6 \mu \mathrm{g} / \mathrm{mL}$ & Unknown & [71] \\
\hline & Iota/lambda/kappa-carrageenan & Hepatitis A Virus (HAV) & Ratio of $\mathrm{CD}_{50}$ to $\mathrm{ED}_{50}>400$ & Inhibit replication & [72] \\
\hline \multicolumn{6}{|c|}{ Green Algae } \\
\hline Enteromorpha compressa & Ulvan & HSV & $\mathrm{IC}_{50}=28.25 \mu \mathrm{g} / \mathrm{mL}$ & Inhibit adsorption and replication & {$[74,75]$} \\
\hline Ulva intestinalis & Ulvan & Measles virus (MeV) & $\mathrm{IC}_{50}=3.6 \mu \mathrm{g} / \mathrm{mL}$ & Reduce the formation of syncytia & [77] \\
\hline Ulva clathrata & Ulvan & NDV & $\mathrm{IC}_{50}=0.1 \mu \mathrm{g} / \mathrm{mL}$ & $\begin{array}{l}\text { Inhibit cell-cell fusion via a direct effect } \\
\text { on F0 protein }\end{array}$ & [78] \\
\hline Ulva armoricana & Ulvan (enzymatic preparations) & HSV-1 & $\mathrm{EC}_{50}=320.9-373.0 \mu \mathrm{g} / \mathrm{mL}$ & Unknown & [79] \\
\hline Monostroma nitidum & Rhamnan Sulfate & $\begin{array}{l}\text { HSV-1, HSV-2, HCMV, MeV, } \\
\text { MuV, HCV, HCoV and HIV }\end{array}$ & $\mathrm{EC}_{50}=0.77-8.30 \mu \mathrm{g} / \mathrm{mL}$ & Inhibit viral proliferation & {$[80]$} \\
\hline Monostroma nitidum & Rhamnan Sulfate & HSV-2 & $\mathrm{IC}_{50}=0.87 \mu \mathrm{g} / \mathrm{mL}$ & $\begin{array}{l}\text { Suggested to inhibit adsorption } \\
\text { or penetration }\end{array}$ & {$[81]$} \\
\hline Gayralia oxysperma & Sulfated heterorhamnan & HSV-1 and HSV-2 & $\mathrm{IC}_{50}=0.036-0.3 \mu \mathrm{g} / \mathrm{mL}$ & Inhibit multiplication & [82] \\
\hline Codium fragile & Sulfated galactan & HSV-2 & $\mathrm{IC}_{50}=4.7 \mu \mathrm{g} / \mathrm{mL}$ & $\begin{array}{l}\text { Interference with the early steps such as } \\
\text { virus adsorption to and penetration into } \\
\text { host cells }\end{array}$ & [83] \\
\hline $\begin{array}{l}\text { Monostroma nitidum, } \\
\text { C. okamurai, C. scapelliformis, } \\
\text { Chaetomorpha crassa, } \\
\text { C. spiralis, Codium adhaerens, } \\
\text { C. fragile, Caulerpa brachypus } \\
\text { and Caulerpa latum }\end{array}$ & Sulfated arabinoxylogalactan & HSV-1 & $\mathrm{IC}_{50}=0.38-8.5 \mu \mathrm{g} / \mathrm{mL}$ & $\begin{array}{l}\text { Inhibit binding, penetration, and the late } \\
\text { stages of replication }\end{array}$ & [84] \\
\hline Enteromorpha compressa & $\begin{array}{l}\text { Sulfated heteroglycuronan } \\
\text { (chemically modified) }\end{array}$ & HSV-1 & $\mathrm{IC}_{50}=28.25 \mu \mathrm{g} / \mathrm{mL}$ & Inhibit replication & {$[74]$} \\
\hline Ulva lactuca & Ulva sulfated polysaccharide extracts & JEV & $0.75 \mathrm{mg} /$ day for 7 days & The survival rate significantly increased & [85] \\
\hline
\end{tabular}


Table 1. Cont.

\begin{tabular}{|c|c|c|c|c|c|}
\hline Sources & Compounds & Activity & Efficacy & Mode of Action & References \\
\hline Ulva Pertusa & Ulvan & Avian InfAV & $\begin{array}{l}50 \mathrm{mg} \text { twice (INJ) } \\
\text { immunizations dose }\end{array}$ & $\begin{array}{l}\text { Enhance AIV-specific antibody } \\
\text { production and improve the humoral } \\
\text { immunity level }\end{array}$ & [86] \\
\hline Caulerpa racemosa & Sulfated heteropolysaccharide & DENV-2 & $\mathrm{IC}_{50}=0.6 \mu \mathrm{g} / \mathrm{mL}$ & Interfere with virus multiplication & [87] \\
\hline \multicolumn{6}{|c|}{ Blue-Green Algae } \\
\hline Spirulina platensis & Calcium Spirulan (Ca-SP) & $\begin{array}{l}\text { HSV-1, HCMV, MeV, MuV, } \\
\text { InfA, HIV-1 }\end{array}$ & $\mathrm{EC}_{50}=0.92-23 \mu \mathrm{g} / \mathrm{mL}$ & Inhibit replication and penetration & [88] \\
\hline Spirulina platensis & $\begin{array}{l}\text { Calcium spirulan, Sodium spirulan, } \\
\text { and potassium spirulan }\end{array}$ & HSV-1 & $\mathrm{IC}_{50}=0.46-0.88 \mu \mathrm{g} / \mathrm{mL}$ & Inhibit replication & [89] \\
\hline Spirulina platensis & $\begin{array}{l}\text { Spirularin }{ }^{\circledR} \text { HS “Ocean Pharma } \\
\text { (Topical cream containing Ca-SP in } \\
\text { combination with SPME) }\end{array}$ & HSV-1 & $\begin{array}{l}15 \mathrm{mg} / \mathrm{g} \text { twice daily for } 3 \\
\text { weeks(10 mg/g SPME) }\end{array}$ & $\begin{array}{l}\text { Significantly prevent herpes labialis } \\
\text { exacerbation }\end{array}$ & {$[90]$} \\
\hline Aphanothece sacrum & Sulfated polysaccharides (ASWPH) & HSV-2 and Inf A (H1N1) & $\mathrm{IC}_{50}=0.32-1.2 \mu \mathrm{g} / \mathrm{mL}$ & Inhibit adsorption & [91] \\
\hline Spirulina maxima & Hot water extract (HWE) & $\begin{array}{l}\text { HSV-1, HSV-2, HCMV, and } \\
\text { pseudorabies virus (PRV) }\end{array}$ & $\mathrm{ED}_{50}=0.069-0.333 \mathrm{mg} / \mathrm{mL}$ & Inhibit adsorption and penetration & [92] \\
\hline $\begin{array}{c}\text { Red; } \\
\text { Porphyridium sp. }\end{array}$ & cell-wall sulphated polysaccharide & $\begin{array}{l}\text { HSV-1, HSV-2 and Varicella } \\
\text { Zoster Virus (VZV) }\end{array}$ & $\mathrm{IC}_{50}=1 \mu \mathrm{g} / \mathrm{mL}$ & $\begin{array}{l}\text { Prevent adsorption and/or inhibit the } \\
\text { production of new viral particles }\end{array}$ & [93] \\
\hline $\begin{array}{c}\text { Diatom; } \\
\text { Navicula directa }\end{array}$ & Naviculan & HSV-1, HSV-2, HIV, and Inf A & $\mathrm{IC}_{50}=7.4-170 \mu \mathrm{g} / \mathrm{mL}$ & $\begin{array}{l}\text { Inhibit binding and penetration. Inhibit } \\
\text { cell-cell fusion between HIV gp160- } \\
\text { and CD4. }\end{array}$ & [94] \\
\hline Gyrodinium impudium & P-KG03 & InfA H1N1 and H3N2 & $\mathrm{EC}_{50}=0.19-0.48 \mu \mathrm{g} / \mathrm{mL}$ & Inhibit replication and entry & [95] \\
\hline Gyrodinium impudicum & P-KG03 & EMCV & $\mathrm{EC}_{50}=26.9 \mu \mathrm{g} / \mathrm{ml}$ & Inhibit replication & [96] \\
\hline Cochlodinium polykrikoides & $\begin{array}{l}\text { Extracellular sulfated polysaccharides } \\
\text { (A1 and A2) }\end{array}$ & $\begin{array}{l}\text { HIV-1, HSV-1, Inf A, RSV-A, } \\
\text { and RSV-B }\end{array}$ & $\mathrm{EC}_{50}=1.1-4.52 \mu \mathrm{g} / \mathrm{mL}$ & Inhibit replication & [97] \\
\hline \multicolumn{6}{|c|}{ Marine animal-derived sulfated polysaccharides } \\
\hline Thelenota ananas & $\begin{array}{l}\text { Sea cucumber Fucosylated chondroitin } \\
\text { sulfate }\end{array}$ & HIV-1 & $\mathrm{EC}_{50}=0.73-31.86 \mu \mathrm{g} / \mathrm{mL}$ & inhibit the entry and replication & [98] \\
\hline
\end{tabular}


Table 1. Cont

\begin{tabular}{|c|c|c|c|c|c|}
\hline Sources & Compounds & Activity & Efficacy & Mode of Action & References \\
\hline Stichopus japonicus & $\begin{array}{l}\text { Sea cucumber sulfated polysaccharide } \\
\text { (SCSP) }\end{array}$ & SARS-COV-2 & $\mathrm{EC}_{50}=9.10 \mu \mathrm{g} / \mathrm{mL}$ & Interact with the $S$ glycoprotein & [18] \\
\hline Squid cartilage & Chondroitin sulphate E (CS-E) & DENV & $\mathrm{EC}_{50}=0.52-11.8 \mu \mathrm{g} / \mathrm{mL}$ & Inhibit the entry via targeting E protein & [99] \\
\hline Squid cartilage & Chondroitin sulfate E (CS-E) & HSV-1 and HSV-2 & $\mathrm{IC}_{50}=0.06$ to $0.2 \mu \mathrm{g} / \mathrm{mL}$ & Inhibit binding & {$[100]$} \\
\hline
\end{tabular}


Carrageenans, which are isolated from the cell walls, represent about $30-70 \%$ of the red algal dry weight, and their structure consists of linear chains of alternating galactopyranose units with linkages between 1 and 3 monomeric positions and other galactopyranose units with linkages between 1 and 4 monomeric positions or 3,6-galactopyranose units. The most important and extensively studied carrageenans are kappa $(\kappa)$, iota, and lambda $(\lambda)$, which vary in the number and position of sulfate ester groups $(S)$, in accordance with the presence of 3,6-anhydrous-D-galactopyranose units [4]. Carrageenans are broadspectrum antivirals and have recently shown significant inhibitory effects by preventing the physical binding and entry of viral particles. Carrageenans were found to be effective against 12 different viruses (HSV, SARS-CoV-2, InfV, hRV, hCoV-OC43, HIV, DENV, hCV, HPV, RVFV, JEV, and TMV). Additionally, carrageenans are the most investigated class in human clinical trials against various virus diseases, such as sexually transmitted HIV, HPV, and HSV, in addition to rhinoviruses [101]. The most successful antiviral preparations of carrageenans were the nasal spray dosage forms that have recently been developed against rhinoviruses and SARS-CoV-2 [6,7,18,43]. Alongside carrageenan and sulfated galactans, other MSPs extracted from red algae and showed considerable activities against HSV, such as sulfated xylomannans, sulfated mannan, sulfated xylogalac tans, and sulfated xylan (Table 1, Figure 2).

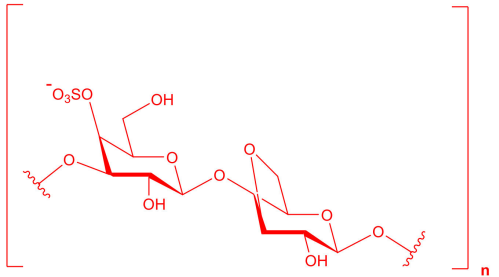

kappa-Carrageenan. In vitro against HSV-1, HSV-2, HIV-1, and DENV-2. $\mathrm{IC}_{50} 0.5-5.6 \mathrm{ug} / \mathrm{mL}$. In vivo against $\mathrm{TMV}$

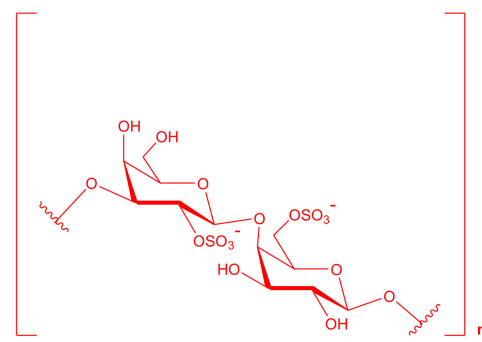

DL-galactan hybrid C2S-3. In vitro against DENV-2 $\mathrm{IC}_{50} 0.8-16 \mathrm{ug} / \mathrm{mL}$

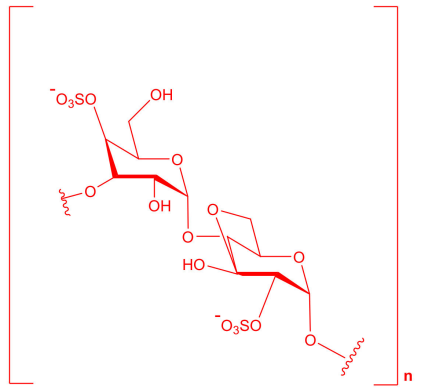

iota-Carrageenan. In vitro against SARS-CoV-2, hRVla, hRV8, hCoV-OC43, HIV-1, H1N1, H3N2, HPV, DENV-2. $\mathrm{IC}_{50} 0.005-6.2 \mathrm{ug} / \mathrm{mL}$. In clinical trial against hRV, hCV, hRVla, CoV OC43, and InfA H1N1n. In market as Xylometazoline $\mathrm{HCl}$ nasal spray and Coldamaris ${ }^{\circledR}$ lozenges.

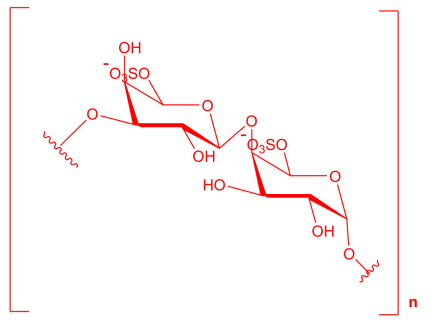

Sulfated galactan. In vitro against HSV-1 and HSV-2 $\mathrm{IC}_{50} 0.19-0.24 \mathrm{ug} / \mathrm{mL}$

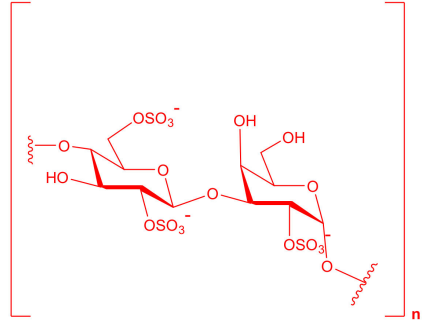

lambda-carrageenan. In vitro against SARSCoV-2 and InfV A \& B; $\mathrm{EC}_{50} 0.3-1.4 \mathrm{ug} / \mathrm{mL}$; DENV-2 and DENV-3; $\mathrm{EC}_{50} 0.14-4.1 \mathrm{ug} / \mathrm{mL}$ HIV-1, HSV-1, HSV-2, RVFV; IC 50 0.4 - 3.3 $\mathrm{ug} / \mathrm{mL}$.

In vivo against DENV-2 and DENV-3.

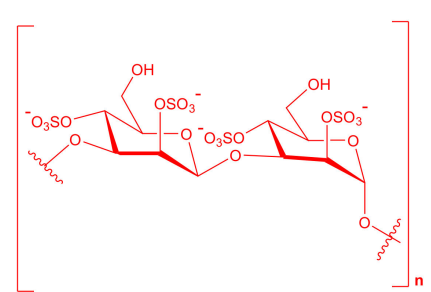

Sulfated mannan. In vitro against HSV-1 $\mathrm{IC}_{50} 5.43-9.68 \mathrm{ug} / \mathrm{mL}$

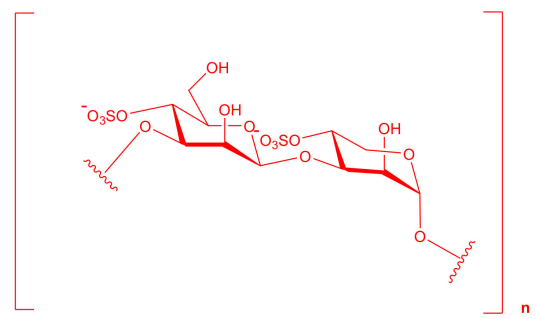

Sulfated xylomannan. In vitro against HSV-1 and HSV-2 $\mathrm{IC}_{50} 0.5 \mathrm{ug} / \mathrm{mL}$

Figure 2. Representative MSPs from red algae. 


\subsection{MSPs from Brown Algae}

Brown algae come in second place after red algae in terms of antiviral activities and research attention (Figure 1). The main reported MSPs from this genus were fucoidans, a group of heterogeneous sulfated polysaccharides that represent about $25-30 \%$ of the algae dry weight and are made up of a backbone of $\alpha-(1 \rightarrow 3)$-L-fucopyranose residues or alternating $\alpha-(1 \rightarrow 3)$ and $\alpha-(1 \rightarrow 4)$-linked L-fucopyranosyls with a sulfate group mainly substituted on C-2 or C-4 fucopyranose residues [4]. Fucoidans were found to be effective against 7 different viruses (HSV, SARS-CoV-2, InfAV, HIV-1, DENV-2, NDV, and HCMV) (Table 1, Figure 3 and Figure S1).

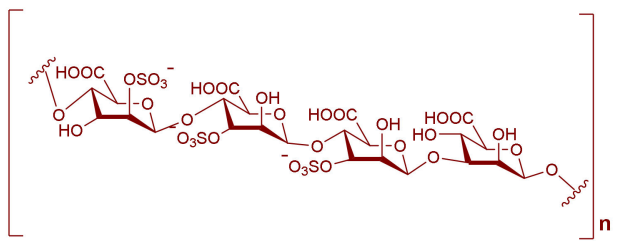

Sulfated polymannuroguluronate (SPMG). In vitro against HIV-1 $\mathrm{IC}_{50} 30 \mathrm{ug} / \mathrm{mL}$

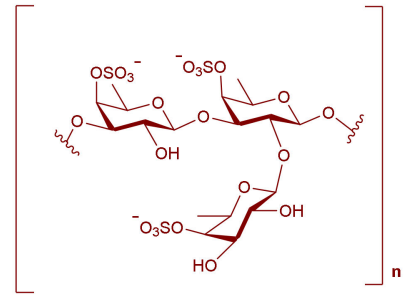

Fucoidan. (1,4)- and (1,3)- $\alpha$-L-fuc. In vitro against HSV-1, HSV-2 $\mathrm{EC}_{50} 0.63$ $-10.0 \mathrm{ug} / \mathrm{mL}$

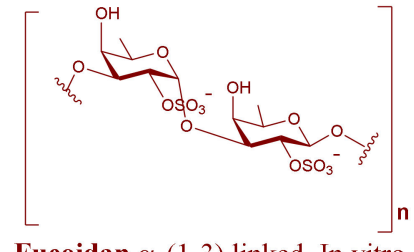

Fucoidan $\alpha-(1-3)$ linked. In vitro against SARS-CoV-2, $\mathrm{IC}_{50} 15.6 \mathrm{ug} / \mathrm{mL}$

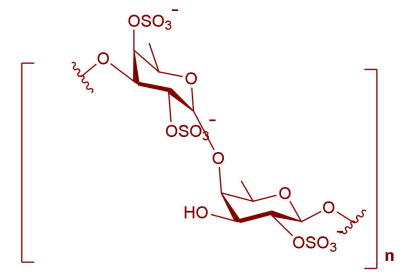

Fucoidan (1-4)- $\alpha$-L-fuc. In vitro against HSV1 , HSV-2 EC $_{50} 0.63-10.0 \mathrm{ug} / \mathrm{mL}$

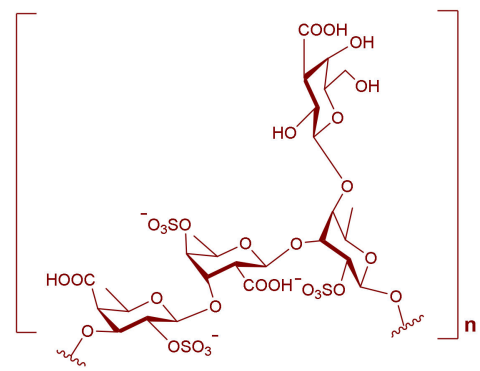

Sulfated galactofucan. In vitro against HSV-1, HSV-2, and HCMV. $\mathrm{IC}_{50} 0.2-1.1 \mathrm{ug} / \mathrm{mL}$

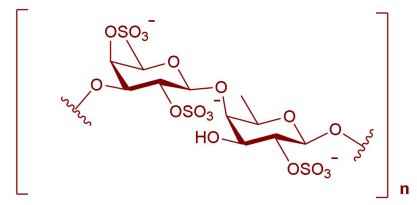

Fucoidan. In vitro against HSV-1, HIV1, and HCMV $\mathrm{IC}_{50} 1-3.3 \mathrm{ug} / \mathrm{mL}$

Figure 3. Representative MSPs from brown algae.

Generally, fucoidans block viral infection by preventing viral entry through competing for the positive charge attachment site of the envelope glycoproteins. The extent of antiviral activity is related to the number of sulfate groups present in the fucoidan structure [102]. As illustrated in Table 1, fucoidans have been tested in vivo using mice or mouse models for their activity against InfAV and HSV-2 and showed promising results. A recent in vitro study of two different fucoidans revealed that these compounds could be potent inhibitors of SARS-CoV-2 [17,18].

\subsection{MSPs from Green Algae}

Green-algae-derived MSPs come in third place as the most-investigated algae. Most of the examined compounds for antiviral activities belong to Ulvanes (Monostroma, Ulva, Enteromorpha), Codium, and Caulerpa. Different green-algae-derived MSPs were studied in vitro and in vivo against 11 viruses, including avian InfAV, HSV, HCMV, DENV-2, EV71, $\mathrm{MeV}, \mathrm{NDV}, \mathrm{MuV}, \mathrm{hCV}, \mathrm{HIV}$, and JEV (Table 1, Figure 4). Song and his colleagues examined the antiviral activity of Ulva pertusa against avian InfAV and found that it exhibited a mild antiviral effect ( $40 \%$ viral inhibition). When combined with a vaccine against the same virus, it generated a synergistic effect, which significantly enhanced the production of antibodies by more than two-fold ( $100 \%)$ [86]. Although the antiviral activities of green algae have received less attention than the red and brown, they possess unique antiviral properties against diverse viruses, such as NDV [78] and JEV [85]. 


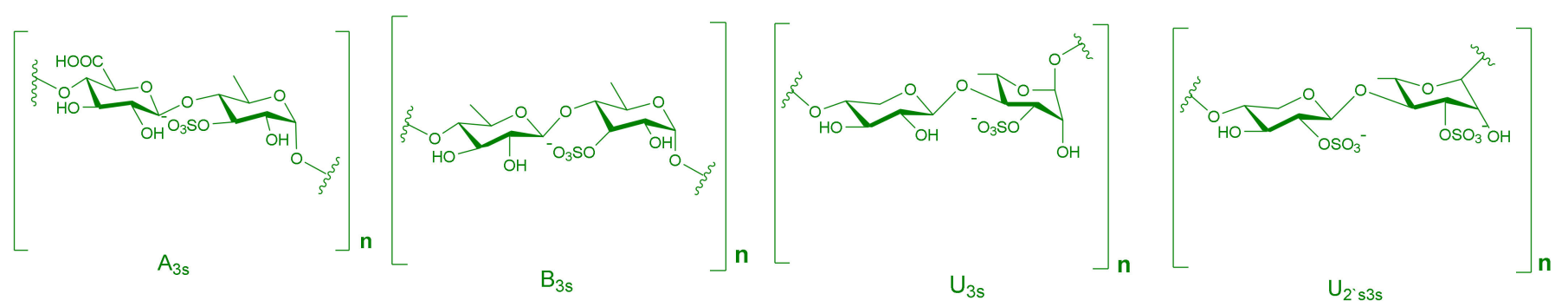

Ulvans. In vitro against $\mathrm{HSV}$ and $\mathrm{MeV} \mathrm{IC}_{50}$ up to $28.25 \mathrm{ug} / \mathrm{mL}$

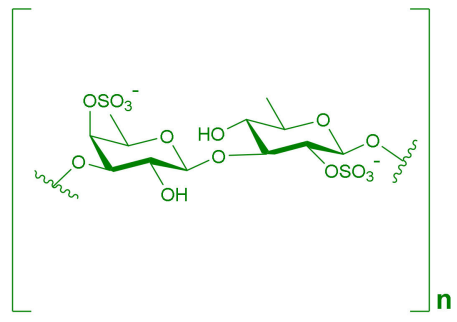

Sulfated heterorhamnan

In vitro against $\mathrm{HSV}-1$ and $\mathrm{HSV}-2 \mathrm{IC}_{50} 0.036-0.3 \mathrm{ug} / \mathrm{mL}$

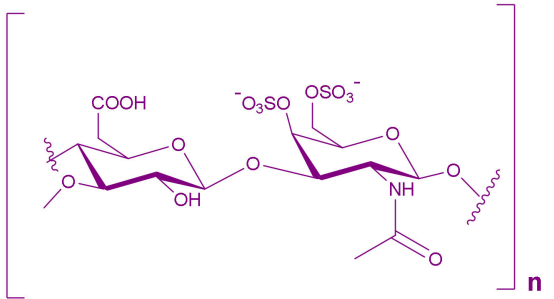

Chondroitin sulphate E (CS-E)

In vitro against $\mathrm{DENV} . \mathrm{EC}_{50} 0.52-11.8 \mathrm{ug} / \mathrm{mL}$

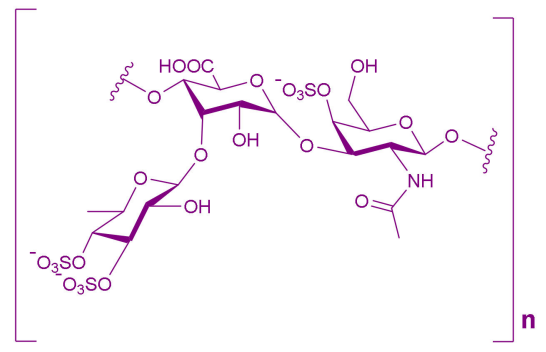

Sea cucumber sulfated polysaccharide (SCSP) In vitro against $\mathrm{SARS}-\mathrm{CoV}-2 \mathrm{EC}_{50} 9.10 \mathrm{ug} / \mathrm{mL}$

Figure 4. Representative MSPs from green algae (green structures), blue-green algae, and marine-animal-derived SPs (violet structures).

\subsection{MSPs from Miscellaneous Marine Sources}

Blue-green algae, microalgae, sea cucumbers, and squid cartilage (Table 1, Figure 4) are studied much less than the former algae for their MSPs as potential antiviral agents. Among them, the novel sulfated polysaccharide calcium spirulan (Ca-SP) was isolated from the blue-green alga Spirulina platensis and found to be an inhibitor for several viruses, including HSV-1, HCMV, InfAV, MeV, HIV-1, and Muv [88]. Recently, a clinical trial confirmed the potential of Ca-SP (Spirularin ${ }^{\circledR} \mathrm{HS}$ ) against herpes viruses through inhibiting the attachment and penetration of HSV-1 into mammalian epithelial cells and blocking the entry of Kaposi sarcoma-associated herpesvirus HSV-8 [90]. The highly sulfated polysaccharide p-KG03 isolated from the microalgae Gyrodinium impudium showed potent inhibitory activity against InfAV by blocking the early stage of replication and entry [95]. Sea cucumber sulfated polysaccharide (SCSP) is one of the most recent MSPs extracted from the sea cucumber Stichopus japonicus. Song and colleagues confirmed its activity against SARS-CoV-2 in an in vitro study through binding to the S-glycoprotein, preventing SARS-CoV-2 host cell entry [18].

\subsection{In Silico Investigation of MSPs against SARS CoV-2}

Molecular modeling of polysaccharides is not an easy task due to their high diversity, complexity, and flexibility; however, the recent advances with in silico tools can relieve the 
complexity of the process to a greater extent. Recently, heparin (10), an example of sulfated polysaccharide, was reported to exhibit a promising antiviral activity against SARS CoV-2 $\left(\mathrm{EC}_{50}=36 \mu \mathrm{g} / \mathrm{mL}\right)$ through S-protein binding; hence, it suppresses the viral attachment to ACE2 (SARS CoV-2 S-protein receptor) and subsequently its entry inside the host cell (Figure 5) [17,103]. Similarly, most of the reported MSPs were found to mediate their antiviral activity via the exact mechanism, particularly those reported as anti-SARS CoV-2.

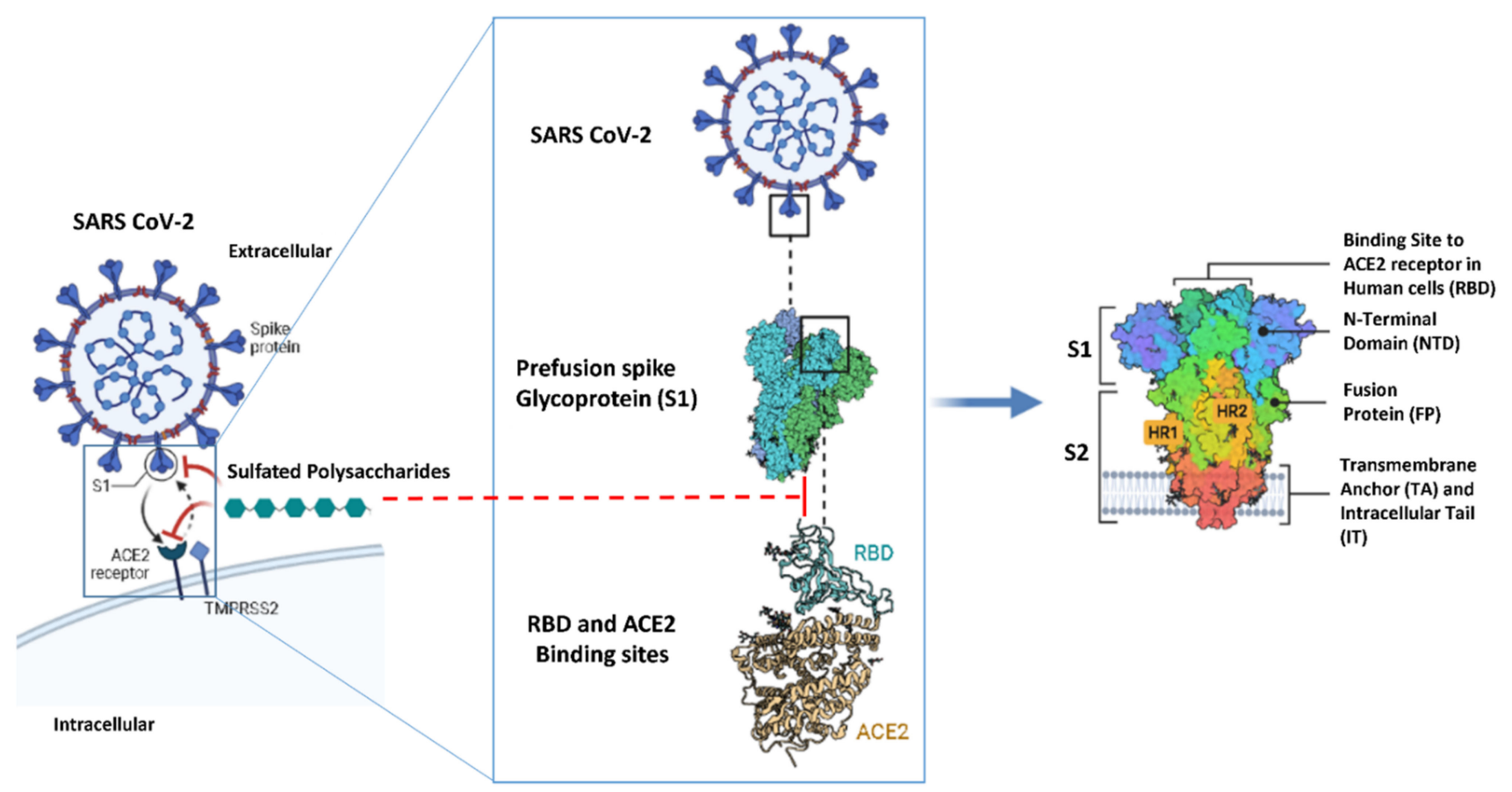

Figure 5. Schematic representation of the structure of SARS CoV-2 S-protein and how it can bind to the human ACE2. (PDB code: 6VXX) [104].

Accordingly, in this study, we shed light on MSPs as potential SARS CoV-2 antiviral agents by speculating on their plausible mode of action at the molecular level using a series of molecular docking and dynamic simulation experiments. Firstly, we determined the possible binding sites on both the S-protein receptor-binding domain (S-RBD) and ACE2 for MSPs. To do so, we utilized ClusPro [105], a software specialized in the prediction of heparin (10) (i.e., as an example of sulfated polysaccharide) binding sites in any given protein via molecular docking. The predicted heparin-S-RBD and heparin-ACE2 complexes were then subjected to $50 \mathrm{~ns}$ molecular dynamic simulation (MDS) experiments to select the most stable binding modes with each protein (S-RBD and ACE2). As shown in Figure 6, heparin was predicted to achieve stable binding with S-RBD at two sites (sites 1 and 2). Site 1 is located in a region that can interact with ACE2 directly and has a moderate positive charge. In contrast, site 2 is shallower than site 1 and is located in a wide positively charged region. Heparin-S-RBD complexes in these two sites were significantly stable over the course of MDS with low deviations from the original poses (RMSD $\sim 2.5 \AA$ ) and minimal fluctuations (site 1 and site 2, Figure 6). This apparent stability resulted from the networks of $\mathrm{H}$-bonds and ionic interactions formed between heparin and each binding site (Tables 2 and 3 ). 


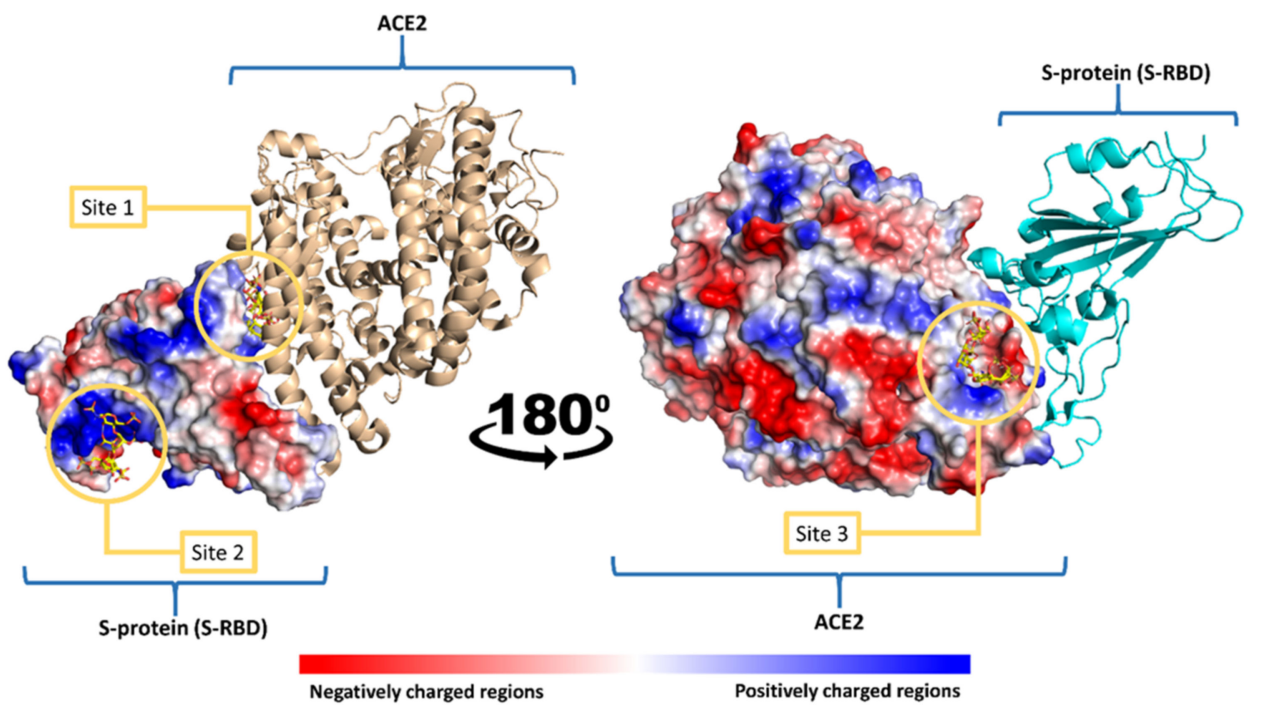

Figure 6. SARS CoV-2's S-RBD-ACE2 complex showing heparin binding sites (sites 1, 2 and 3).

Table 2. Docking scores and binding free energies of the top-scoring MSPS against S-RBD of the original and mutated SARS CoV-2 S-protein (site 1).

\begin{tabular}{|c|c|c|c|c|c|c|c|c|}
\hline \multirow[b]{2}{*}{ No. } & \multirow[b]{2}{*}{ Compound } & \multicolumn{2}{|c|}{ Vina Score $(\mathrm{kcal} / \mathrm{mol}){ }^{\#}$} & \multicolumn{2}{|c|}{$\Delta G^{*}$} & \multicolumn{2}{|c|}{ Average RMSD (Å) } & \multirow{2}{*}{$\begin{array}{c}\text { Reported } \\
\text { Activity } \\
\text { against } \\
\text { SARS CoV-2 }\end{array}$} \\
\hline & & $\begin{array}{l}\text { Original } \\
\text { Strain }\end{array}$ & $\begin{array}{l}\text { Mutated } \\
\text { Strain** }\end{array}$ & $\begin{array}{c}\text { Original } \\
\text { Strain }\end{array}$ & $\begin{array}{l}\text { Mutated } \\
\text { Strain ** }\end{array}$ & $\begin{array}{l}\text { Original } \\
\text { Strain }\end{array}$ & $\begin{array}{l}\text { Mutated } \\
\text { Strain ** }\end{array}$ & \\
\hline 1 & $\begin{array}{l}\text { Sulfated } \\
\text { galactofucan: } \alpha-(1,3)- \\
\text { and }(1,4)-\alpha-\mathrm{L}- \\
\text { (alternating) }\end{array}$ & -6.3 & -6.4 & -6.0 & -6.3 & 5.1 & 4.5 & No \\
\hline 2 & $\begin{array}{l}\text { Sulfated polyman- } \\
\text { nuroguluronate } \\
\text { (SPMG) }\end{array}$ & -7.5 & -6.4 & -7.3 & -5.9 & 2.6 & 4.1 & Yes \\
\hline 3 & Sulfated mannan & -7.6 & -7.7 & -7.2 & -7.4 & 2.3 & 1.9 & No \\
\hline 4 & iota-carrageenan & -6.0 & -6.0 & -0.8 & -0.9 & $>15^{* * *}$ & $>15^{* * *}$ & Yes \\
\hline 5 & lambda-carrageenan & -7.0 & -7.0 & -5.4 & -5.8 & 4.6 & 4.3 & Yes \\
\hline 6 & kappa-carrageenan & -6.6 & -6.4 & -1.3 & -1.9 & $>15^{* * *}$ & $>15^{* * *}$ & Yes \\
\hline 7 & Sulfated galactan & -6.2 & -6.3 & -0.4 & -0.1 & $>15^{* * *}$ & $>15^{* * *}$ & No \\
\hline 8 & $\begin{array}{c}\text { Sulfated } \\
\text { heterorhamnan }\end{array}$ & -6.1 & -6.2 & -0.1 & -0.7 & $>15^{* * *}$ & $>15^{* * *}$ & No \\
\hline 9 & $\begin{array}{l}\text { Chondroitin sulphate } \\
\text { E (CS-E) }\end{array}$ & -7.6 & -7.5 & -7.1 & -6.1 & 1.1 & 2.8 & No \\
\hline 10 & Heparin & -6.5 & -6.4 & -6.1 & -6.1 & 3.3 & 3.3 & Yes \\
\hline
\end{tabular}

Note: ${ }^{*} \Delta G$ was calculated using FEP method (see Materials and Methods for further information). ${ }^{* *}$ N501Y-mutated strain of SARS CoV-2. *** This compound dissociated early at the beginning of MDS experiments (at $\sim 25 \mathrm{~ns}$ ). \# The reported scores are the averages of three independent docking experiments (standard errors were between 0.1 and 0.3 ).

On the other hand, heparin was predicted to interact with a small pocket (site 3) on ACE2 located near the S-RBD binding region (Figure 6). Similar to sites 1 and 2, heparin achieved stable binding with site 3 during the MDS (RMSD $1.9 \AA$ ) through extensive H-bonds and ionic interactions (site 3, Table 4 and Figure 6). 
Table 3. Docking scores and binding free energies of top-scoring MSPS against RBD of SARS CoV-2 S-protein (site 2).

\begin{tabular}{cccccc}
\hline No. & Compound & $\begin{array}{c}\text { Vina Score } \\
(\mathbf{k c a l} / \mathbf{m o l})\end{array}$ & $\Delta G^{*}$ & $\begin{array}{c}\text { Average RMSD } \\
(\AA)\end{array}$ & $\begin{array}{c}\text { Reported Activity } \\
\text { against SARS CoV-2 }\end{array}$ \\
\hline 1 & $\begin{array}{c}\text { Sulfated galactofucan: } \alpha-(1,3) \text { - and } \\
(1,4)-\alpha \text {-L- (alternating) }\end{array}$ & -5.3 & -5.7 & 2.4 & No \\
\hline 2 & Sulfated polymannuroguluronate (SPMG) & -5.5 & -5.9 & 2.1 & No \\
\hline 3 & Sulfated mannan & -5.4 & -5.1 & 2.6 & No \\
\hline 4 & iota-carrageenan & -5.0 & -1.7 & $>15^{* *}$ & Yes \\
\hline 5 & lambda-carrageenan & -5.5 & -5.4 & 2.5 & Yes \\
\hline 10 & Heparin & -5.0 & -5.8 & 1.9 & Yes \\
\hline
\end{tabular}

Note: ${ }^{*} \Delta G$ was calculated using the FEP method (see Materials and Methods for further information). ${ }^{* *}$ This compound dissociated early at the beginning of MDS (at $\sim 25 \mathrm{~ns}$ ).

Table 4. Docking scores and binding free energies of the top-scoring MSPS against ACE2 (site 3).

\begin{tabular}{cccccc}
\hline No. & Compound & $\begin{array}{c}\text { Vina Score } \\
(\mathbf{k c a l} / \mathbf{m o l})\end{array}$ & $\boldsymbol{\Delta} \boldsymbol{G}^{*}$ & $\begin{array}{c}\text { Average RMSD } \\
(\mathbf{\AA})\end{array}$ & $\begin{array}{c}\text { Reported Activity } \\
\text { against SARS CoV-2 }\end{array}$ \\
\hline 2 & Sulfated polymannuroguluronate (SPMG) & -5.9 & -5.4 & 2.8 & No \\
\hline 5 & lambda -carrageenan & -5.5 & -5.0 & 3.1 & Yes \\
\hline 10 & Heparin & -5.3 & -5.0 & 3.0 & Yes \\
\hline
\end{tabular}

Note: ${ }^{*} \Delta G$ was calculated using FEP method (see Materials and Methods for further information).

The complex stability of RDB-ACE2 was also studied upon heparin binding to each site. As depicted in Figure 4, the distance between S-RBD and ACE2 (calculated as the distance between GLN-493 and GLU-35, respectively) remained constant $(\sim 5.1 \AA)$ over $30 \mathrm{~ns}$ of MDS, while binding of heparin to S-RBD or ACE2 via sites 1, 2, or 3 led to significant instability of the complex and gradual dissociation (i.e., increased distance between GLN-493 and GLU-35). Heparin binding to site 1 on S-RBD or site 3 on ACE2 showed the greatest effects as S-RBD dissociated almost completely from ACE2 after $20 \mathrm{~ns}$ of simulation (Figure 7). Accordingly, it can be concluded that stable binding of SPs to sites 1,2 , or 3 destabilizes the S-RBD-ACE2 complex.
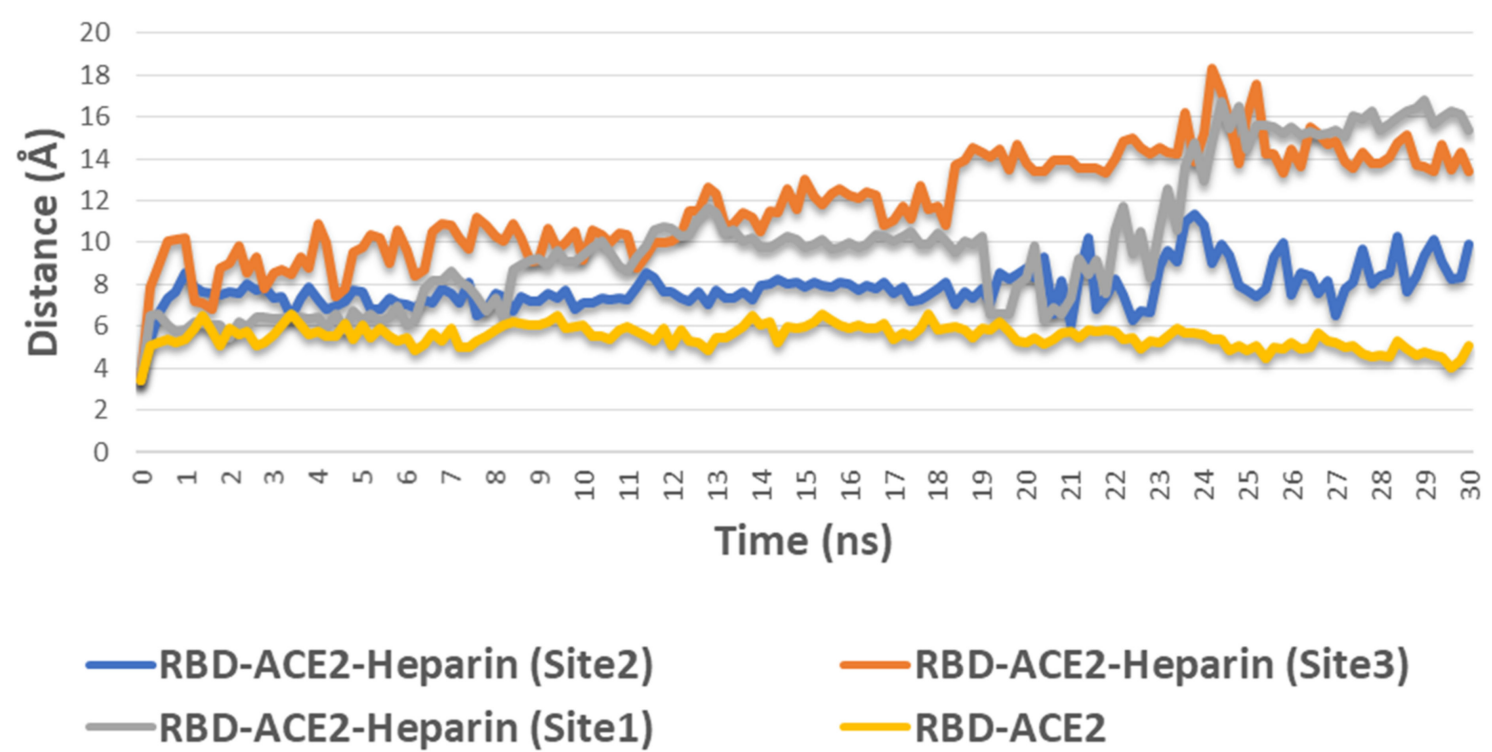

Figure 7. The calculated distance between S-RBD and ACE2 (i.e., between GLN-493 and GLU-35, respectively) during 30 ns of MDS in the absence and presence of heparin in site 1,2, or 3. 
It was recently reported that heparin can bind to S-RBD, preventing SARS CoV-2 from reaching ACE2 and entering the host cell; however, according to our modeling results, heparin can also bind to and block ACE2, acting as a protective agent against SARS CoV-2 infection. To study the mode of action of all reported MSPs against SARS CoV-2 to suggest previously unreported candidates, we subjected all collected compounds (Table 1) to dock against the proposed binding sites (sites 1, 2, and 3). Top-scoring hits (Figure 8) were selected according to the following criteria: (i) Docking score $<-5 \mathrm{kcal} / \mathrm{mol}$. Scores $>-5$ (i.e., -4.9 to $-1.2 \mathrm{kcal} / \mathrm{mol}$ ) showed unstable binding with the corresponding protein (RMSD $>20 \AA$ at the first $20 \mathrm{~ns}$ ); (ii) $\Delta \mathrm{G}$ value $<-5 \mathrm{kcal} / \mathrm{mol}$, (iii) the docking pose remains stable over $50 \mathrm{~ns}$ of MDS. Some compounds achieved docking scores $<-5 \mathrm{kcal} \mathrm{mol}$ (e.g., $-6.4 \mathrm{kcal} \mathrm{mol}$ ), although they were significantly unstable during the MDS experiments (RMSD > $15 \AA$ at the first $20 \mathrm{~ns}$ ) and presented significantly higher $\Delta \mathrm{G}$ values $(\sim-1.3 \mathrm{kcal} / \mathrm{mol})$. As such, we made the binding stability at least $50 \mathrm{~ns}$ alongside $\Delta \mathrm{G}$ value $<-5 \mathrm{kcal} / \mathrm{mol}$ another selection criterion to discriminate between binders from non-binders, ensuring that all selected hits can achieve stable binding with the corresponding protein.

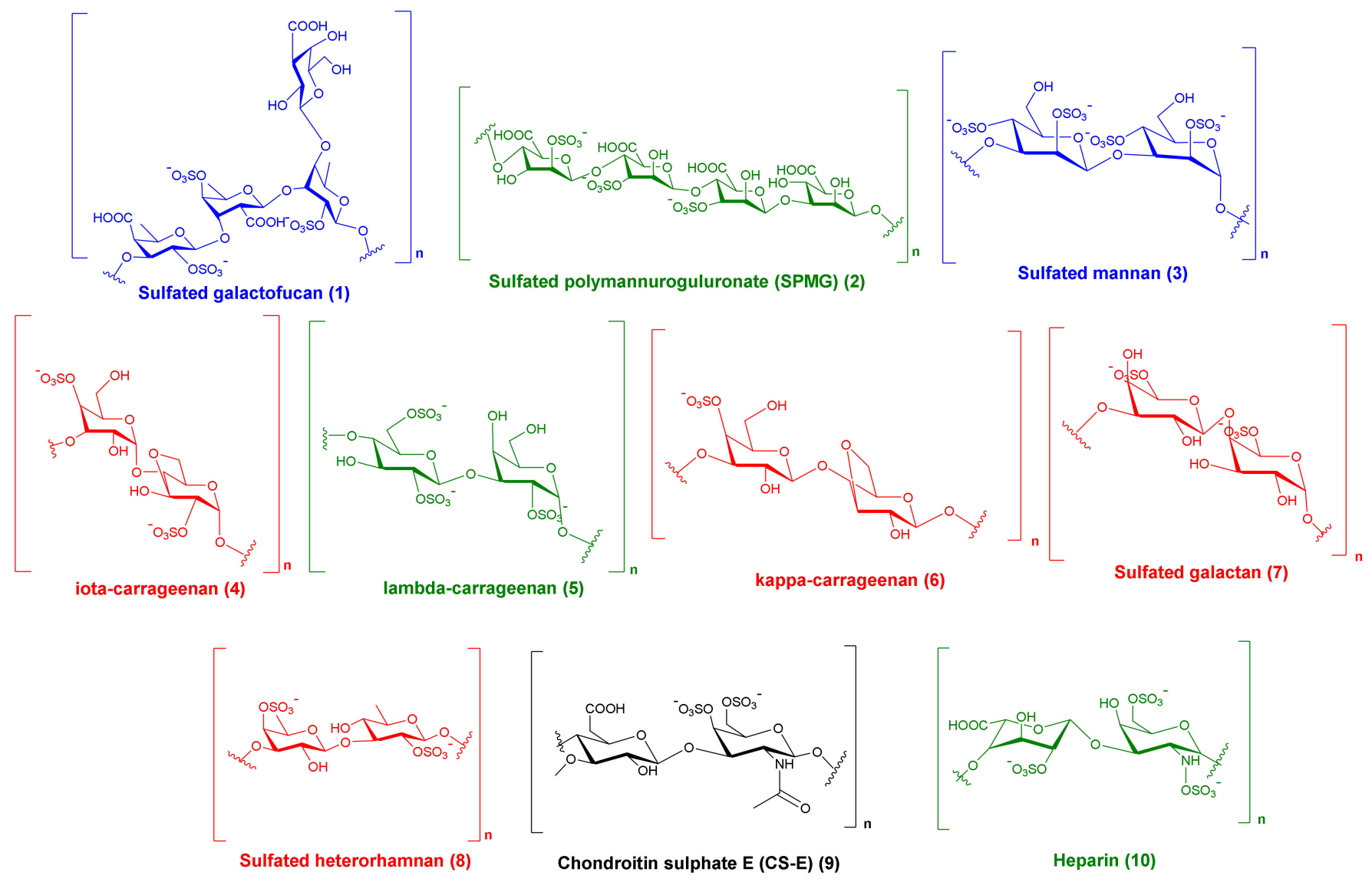

Figure 8. Sulphated polysaccharides with docking scores $<-5 \mathrm{kcal} / \mathrm{mol}$. Red compounds were significantly unstable during the course of MDS experiments. Black compound (compound 9) achieved stable binding with site 1 only. Blue compounds achieved stable bindings with sites 1 and 2. Green compounds achieved stable bindings with sites 1,2 , and 3 .

Additionally, we took into consideration the newly emerged SARS CoV-2 variants during our docking experiments. Upon reviewing the recent mutations of the viral Sprotein, we found that the UK variant (i.e., B.1.1.7) has a mutation in its S-RBD (i.e., N501Y) that was associated with its higher affinity to the ACE2 receptor [106]. This mutation was the replacement of the amino acid ASP-501 with TYR. We applied this mutation to the S-RBD structure to study its effect on the binding with MSPs upon docking and MDS. 
As shown in Table 2, docking against site 1 (with and without the N501Y mutation) resulted in nine SPs with scores $<-5 \mathrm{kcal} / \mathrm{mol}$ (Figure 8 ). Four of these hits were previously reported to exert antiviral activity against SARS CoV-2. Further MDS and $\triangle \mathrm{G}$ experiments revealed that the best binding modes for iota-carrageenan (4), kappa-carrageenan (6), sulfated galactan (7), and sulfated heterorhamnan (8) (Figure 8) with site 1 were significantly unstable (their average RMSD values were higher than $15 \AA$ and their $\Delta G$ values were higher than $-5 \mathrm{kcal} / \mathrm{mol}$ ) and they could easily dissociate from site 1 (with and without the N501Y mutation). Sulfated galactofucan (1), sulfated mannan (3), and chondroitin sulphate E (CS-E) (9) were among the best-scoring hits that were significantly stable during the MDS experiments, either with the mutated or non-mutated RBD. Additionally, they had not been previously reported for their antiviral efficacy against SARS CoV-2; hence, they were considered good candidates for future evaluation.

As shown in Figures 9-14, the prevalent interactions of these MSPs and RBD site 1 in its mutated and non-mutated forms were $\mathrm{H}$-bonds and water bridges, where the sulfate esters were the main contributors in these interactions with site 1 key amino acid residues (Table 2). Moreover, their fluctuations and deviations from the starting docking poses were almost identical to both the mutated and non-mutated form of site 1 during the MDS, except for chondroitin sulphate $\mathrm{E}$, which achieved slightly more stability and less deviation from the starting binding pose upon binding to the non-mutated form of site 1 (Figure 13).

Regarding site 2, only five sulfated polysaccharides presented docking scores $<-5 \mathrm{kcal} / \mathrm{mol}$, of which iota-carrageenan (4) was unstable on MDS (got an average RMSD $>15 \AA$ ) and presented a $\Delta \mathrm{G}$ value higher than $-5 \mathrm{kcal} / \mathrm{mol}$ (i.e., $1.7 \mathrm{kcal} / \mathrm{mol}$ ). Sulfated galactofucan (1), sulfated polymannuroguluronate (SPMG) (2), and sulfated mannan (3) were among the best MSPs that achieved stable binding with S-RBD site 2 and were not previously reported against inhibitory effects of SARS CoV-2 (Table 3). In this site (i.e., site 2), ionic interactions between the negatively charged sulfate moieties and the positively charged key amino acid residues of this site were crucial, along with the other polar interactions (e.g., H-bonding and water bridging), in maintaining stable binding with such shallow binding site (Figures 15-17).

On the other hand, docking against the ACE2 binding site (site 3) revealed that both (SPMG) and lambda-carrageenan were the best-performing MSPs. Additionally, they were also stable over the course of MDS, achieving low deviations from their starting binding poses (RMSD $\sim 2.9 \AA)$ and $\Delta \mathrm{G}$ values $<-5 \mathrm{kcal} / \mathrm{mol}(\sim-5.2 \mathrm{kcal} / \mathrm{mol})$. Lambdacarrageenan was previously identified to bind to SARS CoV-2 S-protein [44]; however, there have been no reports on the ACE2 binding potential of MSPs so far. As such, focusing on this human protein target will be of great interest in future investigations of SPs as anti-COVID-19 therapeutics. Similarly to site 1 and 2, the dominant interactions between these MSPs and the key amino acid residues inside site 3 were also of the polar type (e.g., H-bonds, water bridges, and ionic interactions) (Figures 18 and 19).

\subsection{Structure-Activity Relationship}

The structural complexity of SPs has made the study of their structure-activity relationship quite challenging, and until now it has not been entirely understood; however, certain key bioactivity-related structural features could be concluded from the previously reported studies and the present modeling study.

The first structural determinant that may affect the antiviral potential of this class of compounds is the number of negatively charged groups (e.g., sulfates or carboxylates). Polysaccharides with higher numbers of sulfate or carboxylate groups per monosaccharide were more bioactive. Highly sulfated glucans (either natural or chemically synthesized derivatives) were found to be far more bioactive as antiviral agents than those with lower degrees of sulfation, while non-sulfated glucans were practically inactive $[107,108]$. Moreover, in our modeling study, MSPs with a single sulfate or carboxylate group per monosaccharide did not achieve stable binding with either S-RBD or ACE2 ( $\Delta \mathrm{G}$ values $>-5 \mathrm{kcal} / \mathrm{mol}$ ); hence, we could conclude that electrostatic and other polar interactions mediated by these 
negatively charged groups play a significant role in stabilizing the binding of this class of compounds to S-RBD and ACE2.
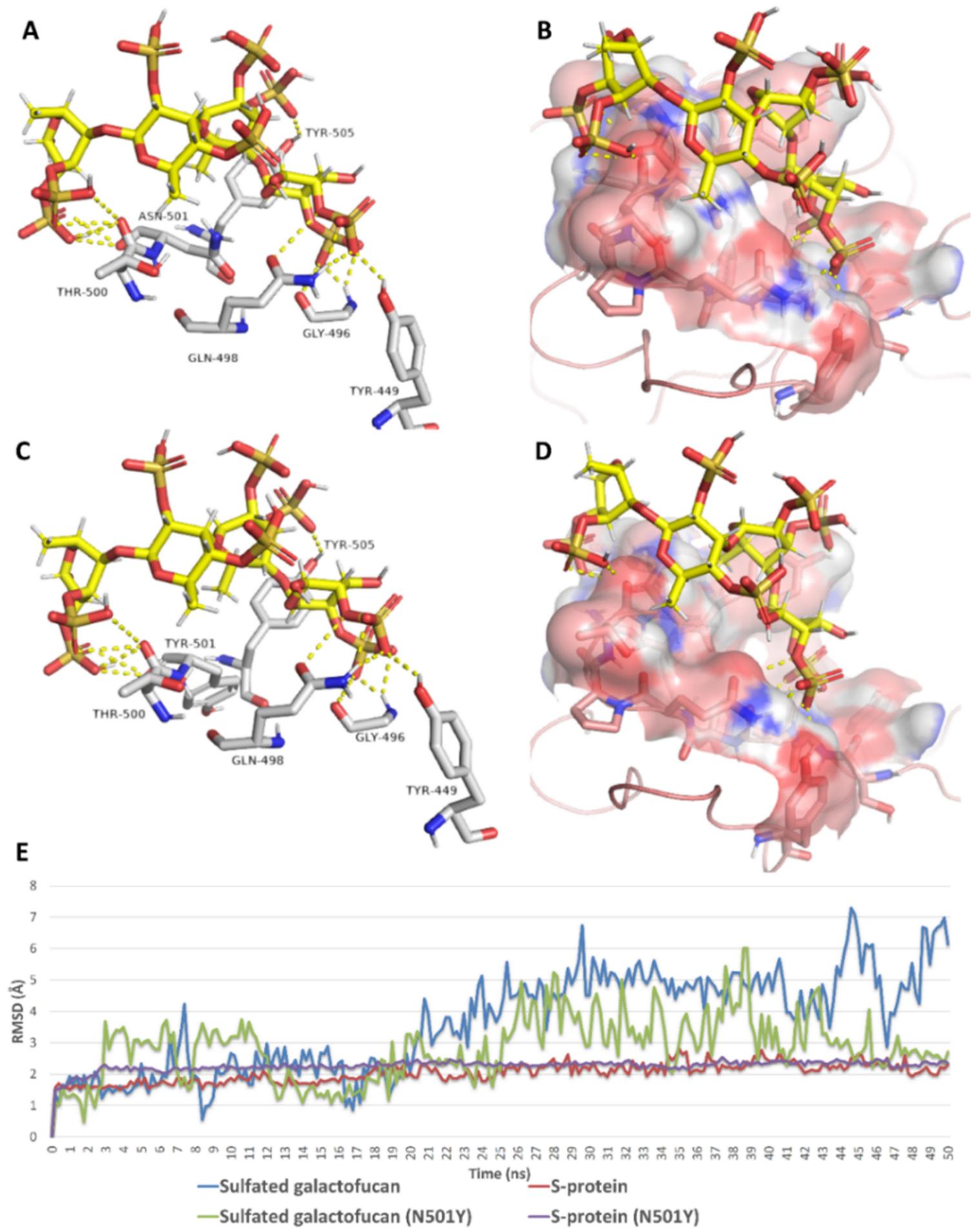

Figure 9. Binding mode of sulphated galactofucan (compound 1) inside site $1(\mathbf{A}, \mathbf{B})$ and its mutated form $(\mathbf{C}, \mathbf{D})$ together with its RMSDs during 50 ns of MDSs (E). 


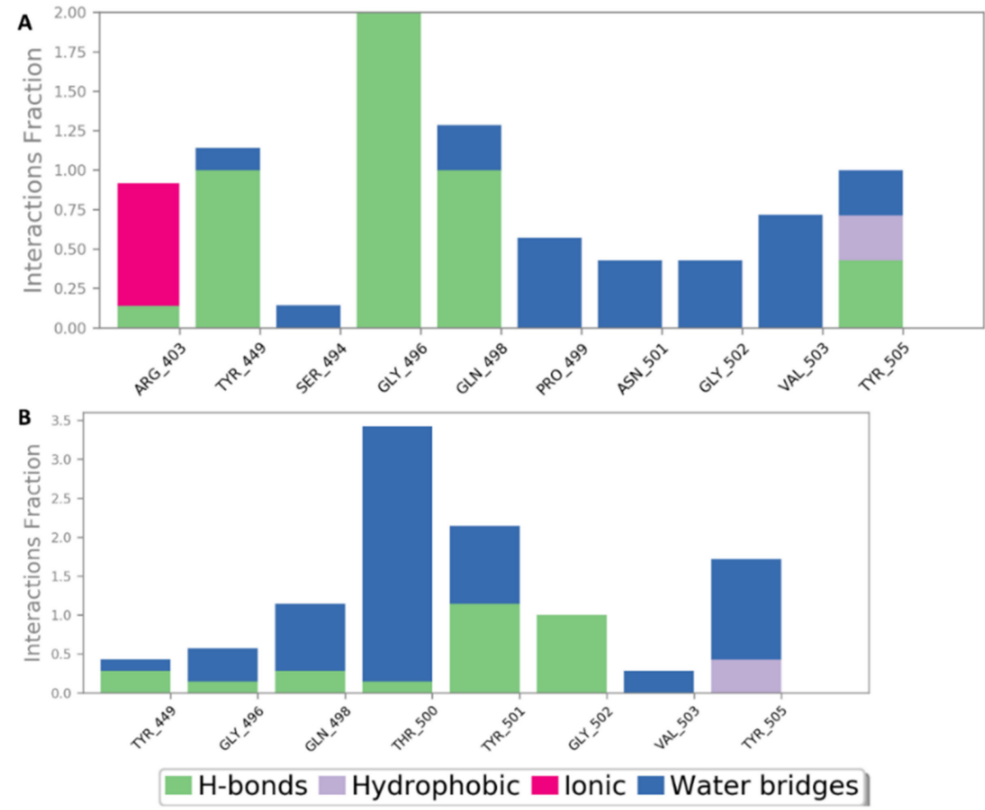

Figure 10. Protein-ligand contacts of sulphated galactofucan (compound 1) inside site 1 (A) and its mutated form (B) during the MDS.
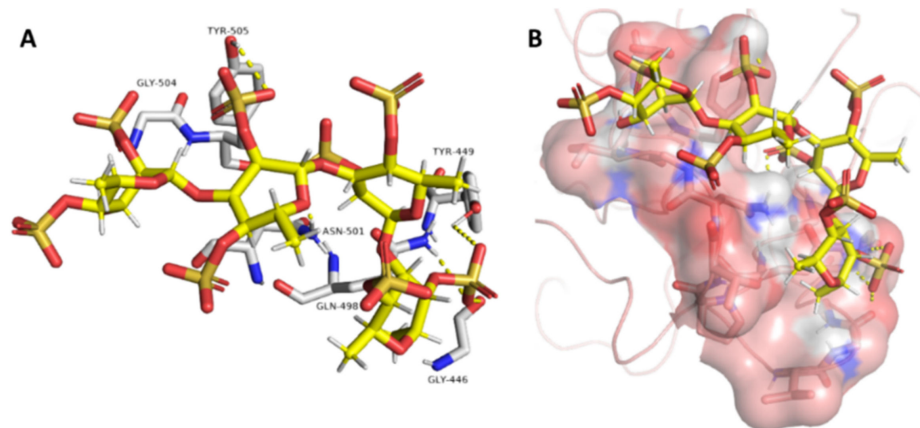

C

D
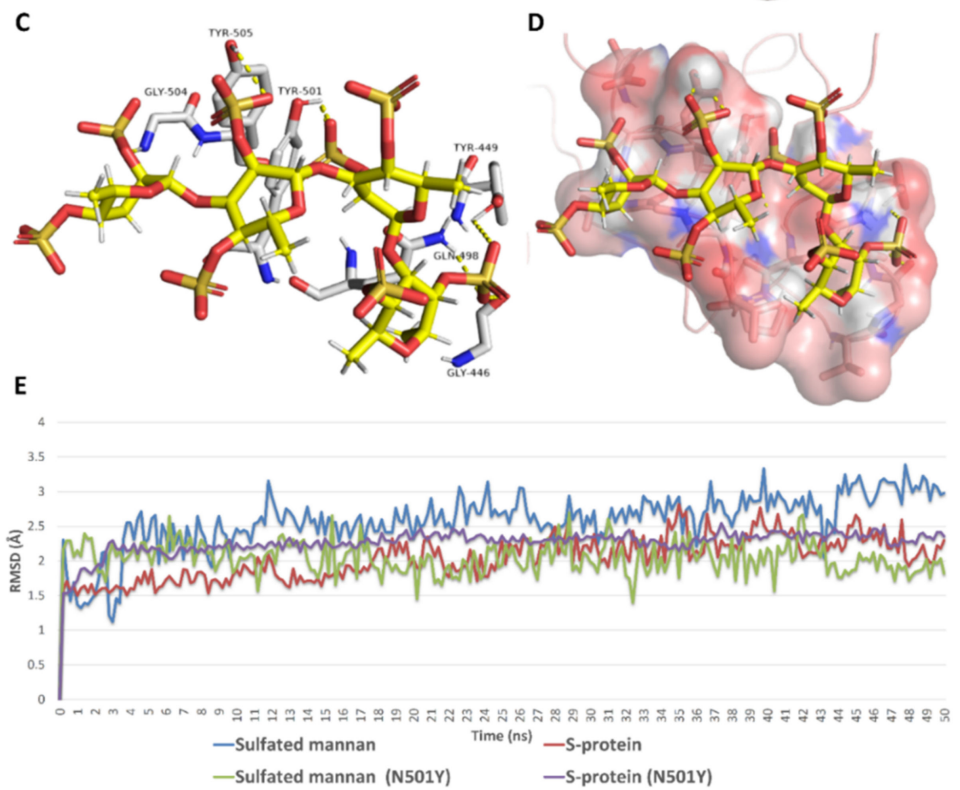

Figure 11. Binding mode of sulfated mannan (3) inside site $1(\mathbf{A}, \mathbf{B})$ and its mutated form (C,D) together with its RMSDs during 50 ns of MDSs (E). 

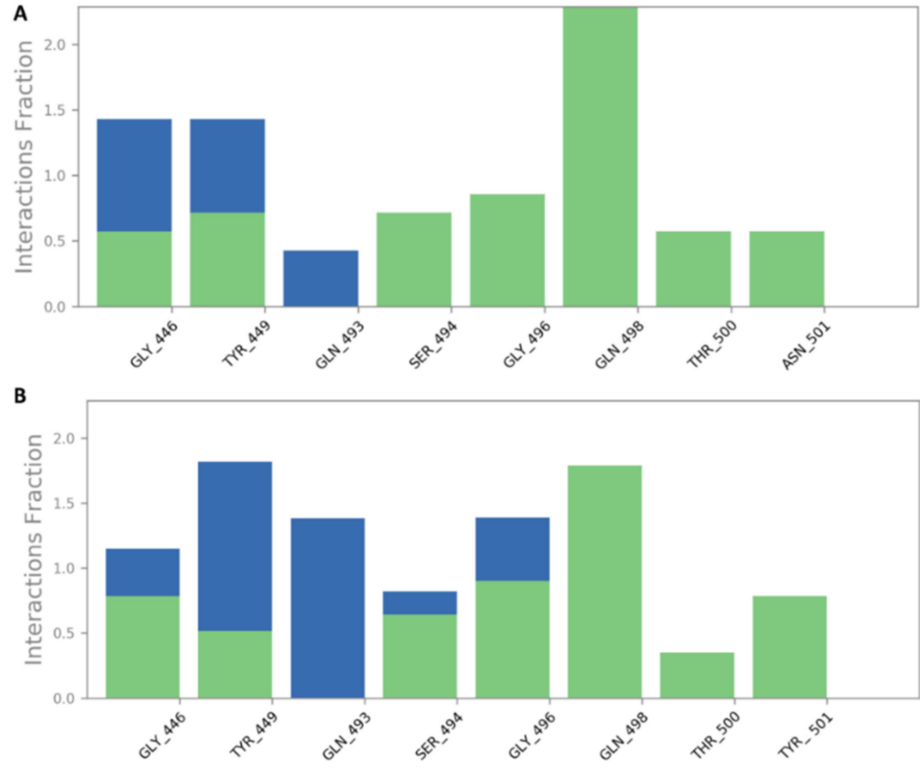

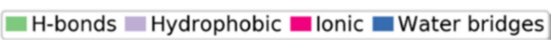

Figure 12. Protein-ligand contacts of sulfated mannan (3) inside site 1 (A) and its mutated form (B) during the MDS.

A

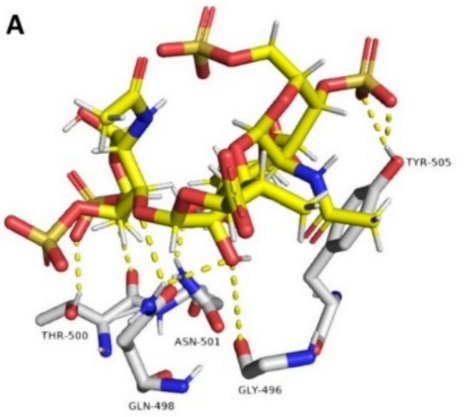

C

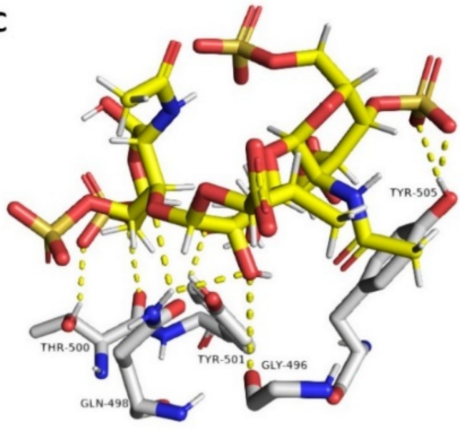

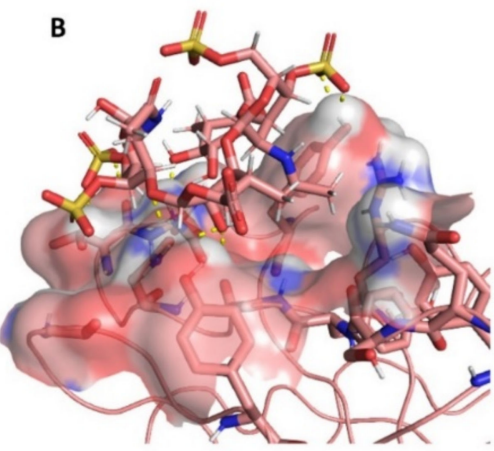

D

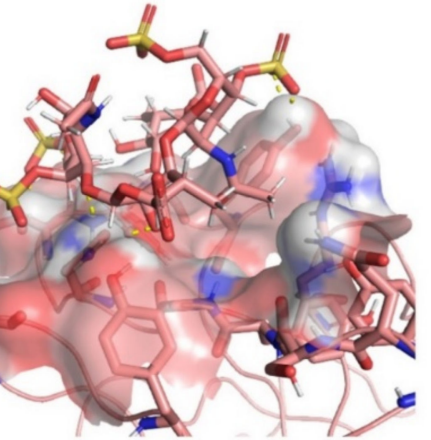

E

4
3.5

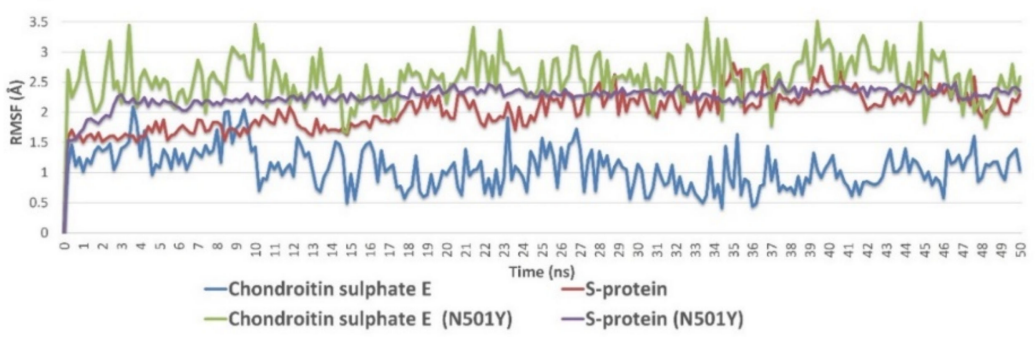

Figure 13. Binding mode of chondroitin sulphate E (compound 9 ) inside site $1(\mathbf{A}, \mathbf{B})$ and its mutated form $(\mathbf{C}, \mathbf{D})$ together with its RMSDs during 50 ns of MDSs (E). 
A
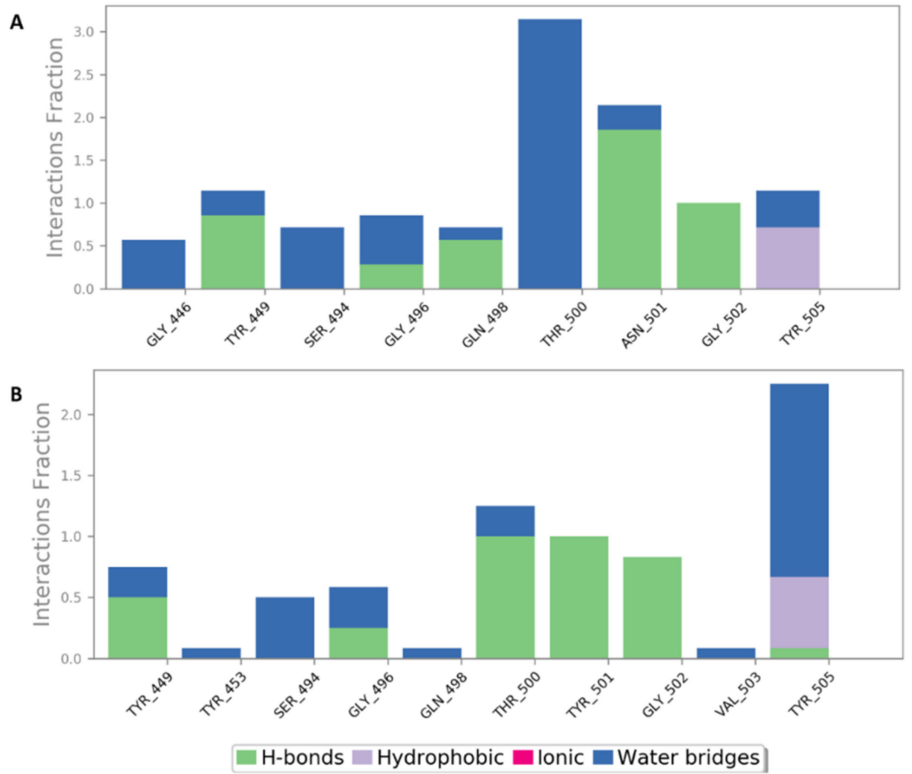

Figure 14. Protein-ligand contacts of chondroitin sulphate E (compound 9) inside site 1 (A) and its mutated form (B) during the MDS.

A

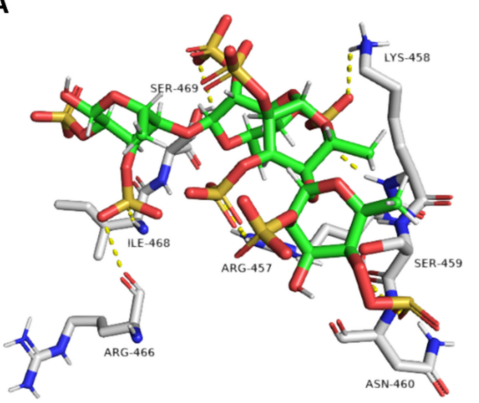

B

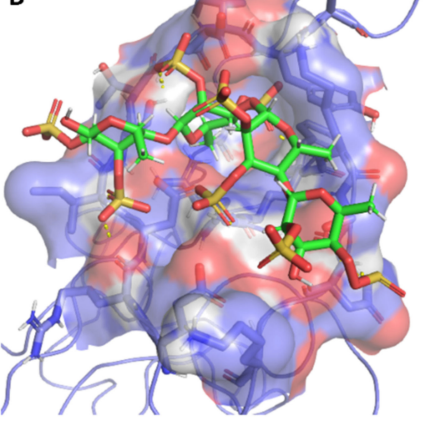

C

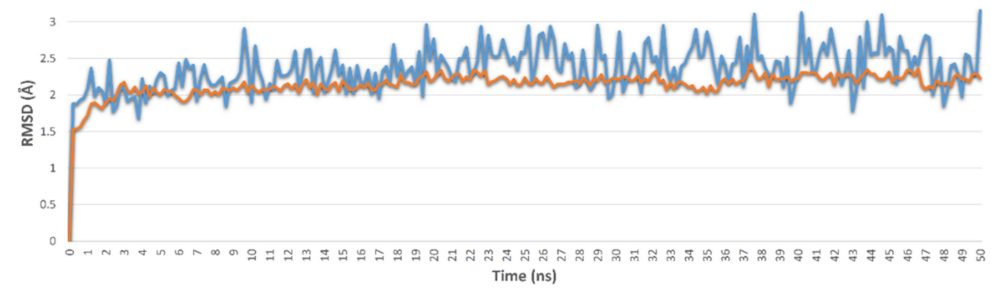

-Sulfated galactofucan $\quad-s$-protein

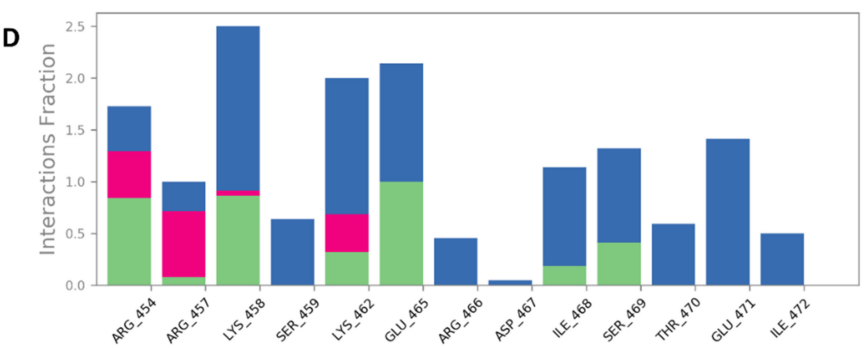

H-bonds Hydrophobic $\quad$ lonic $\square$ Water bridges

Figure 15. Binding mode of sulfated galactofucan (1) inside site $2(\mathbf{A}, \mathbf{B})$ together with its RMSDs and protein-ligand contacts during 50 ns of MDSs (C,D). 


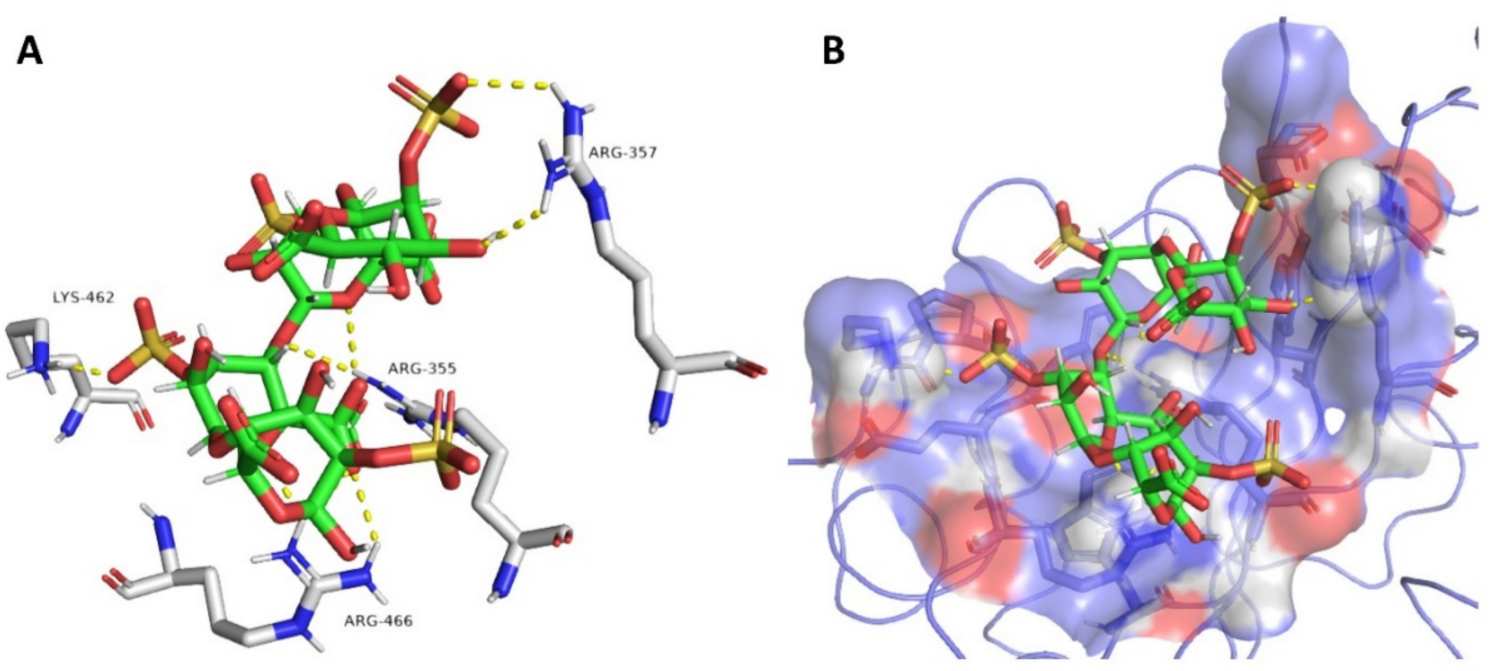

C

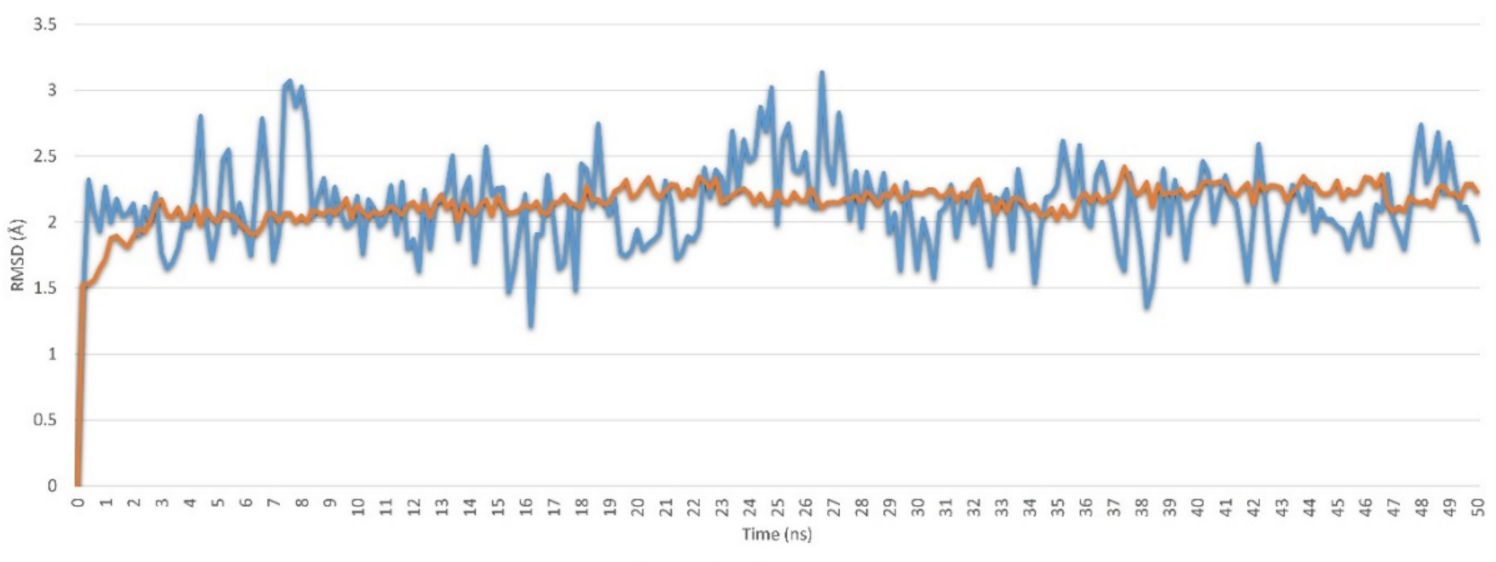

—SPMG —s-protein

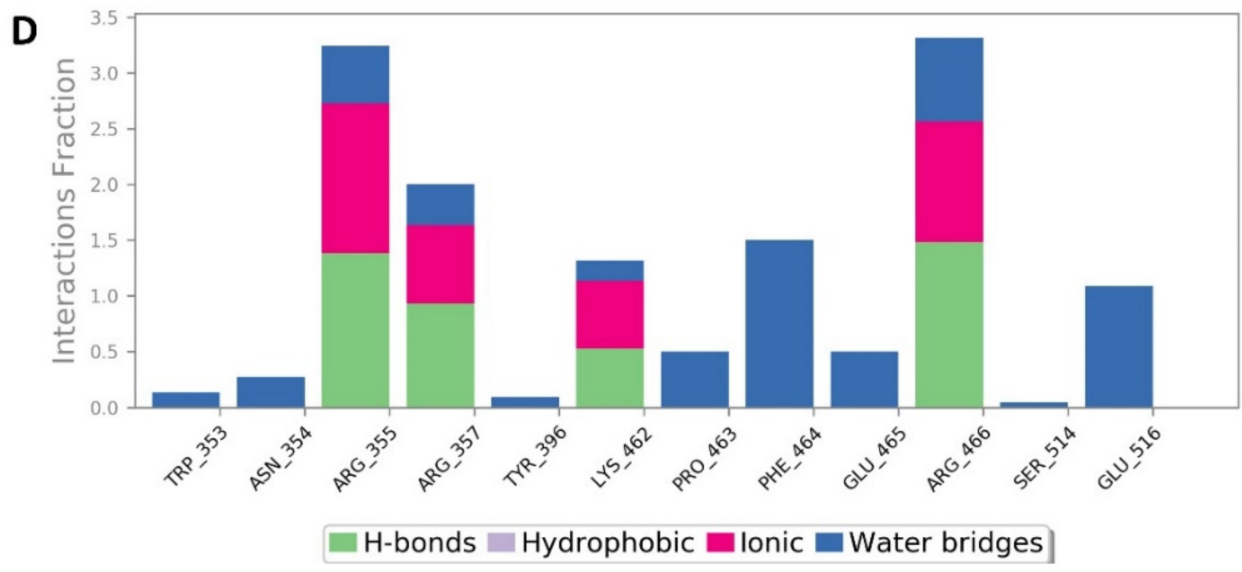

Figure 16. Binding mode of sulfated polymannuroguluronate (SPMG) (compound 2) inside site 2 (A,B) together with its RMSDs and protein-ligand contacts during 50 ns of MDSs (C,D). 
A
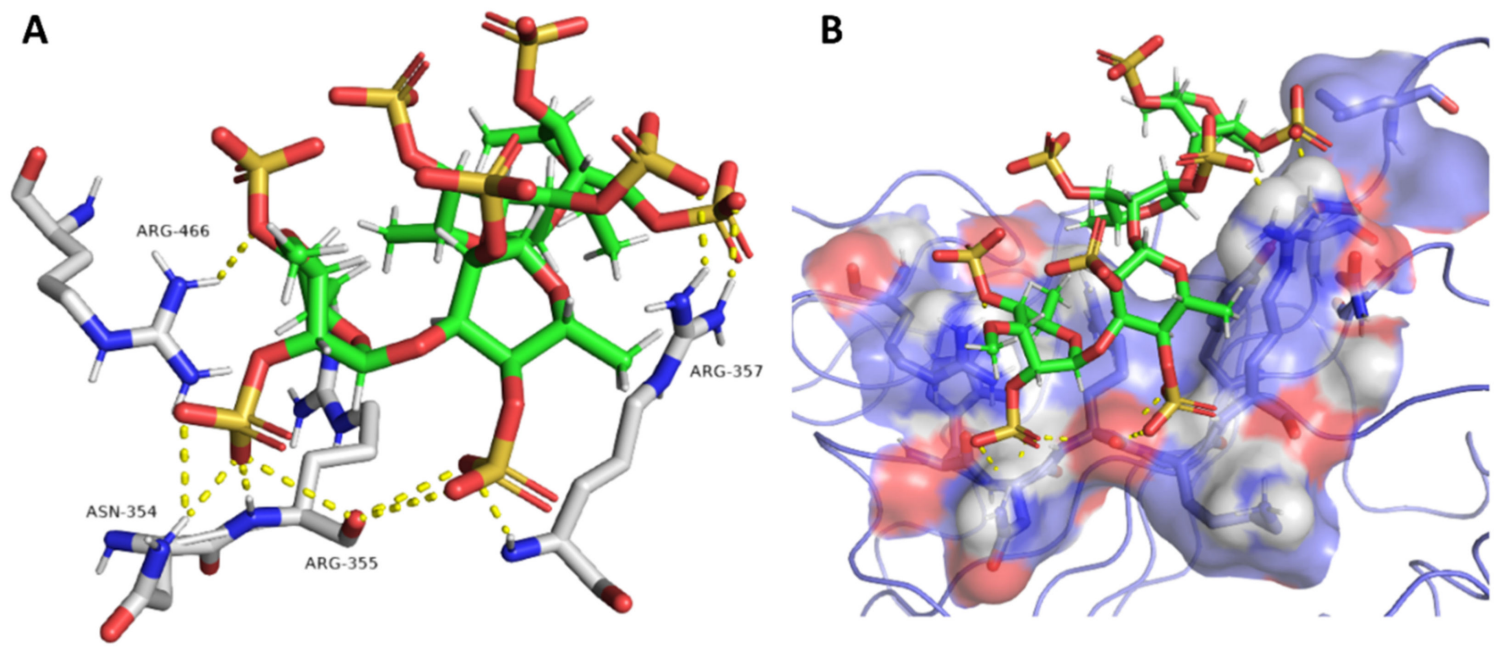

C

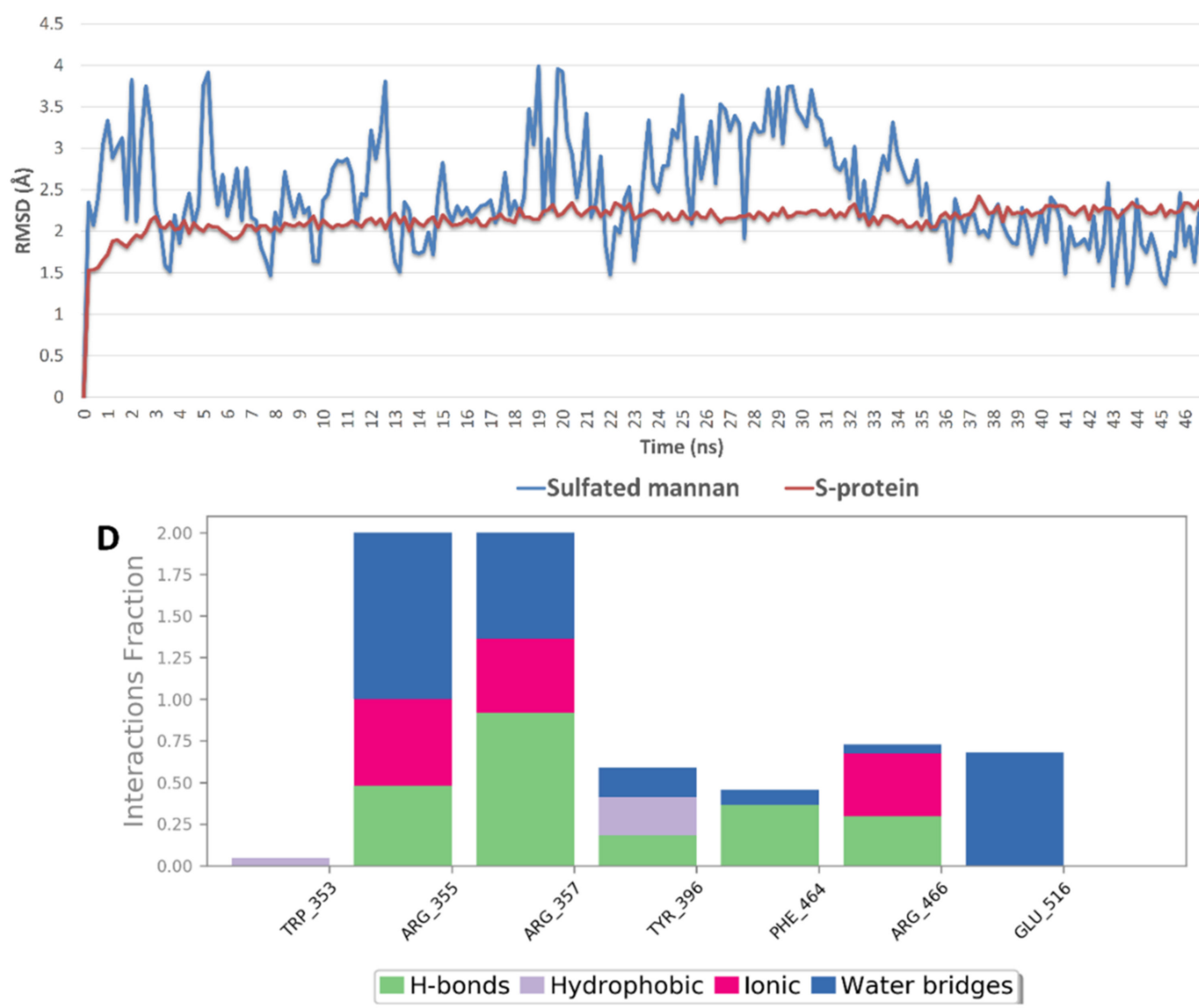

Figure 17. Binding mode of sulfated mannan (compound 3) inside site 2 (A,B) together with its RMSDs and protein-ligand contacts during $50 \mathrm{~ns}$ of MDSs (C,D).

Secondly, the distribution of these negatively charged moieties played an essential role in their antiviral activity. In previous studies, carrageenans with similar degrees of sulfation $(50 \mathrm{~mol} \%)$ but isolated from different sources showed varying antiviral activities $[39,109,110]$. Different charge densities were proposed to explain these findings, and accordingly to explain the antiviral activity [71]. Our modeling study found that neither iota- nor kappa-carrageenan achieved stable binding with any proposed binding sites. 
This could be attributed to their relatively low degree of sulfation (one sulfate group per onosaccharide); however, both were reported to be bioactive against SARS CoV-2 and other pathogenic viruses. This could be explained by the unique distribution of these limited sulfate groups, which might cause them to be bioactive via different modes of action. In contrast, sulfated galactan (7) has a high degree of sulfation (Figure 8); however, it did not achieve stable binding with the proposed binding sites ( $\Delta \mathrm{G}$ value $>-5 \mathrm{kcal} / \mathrm{mol}$ ). Accordingly, the presence of many negatively charged moieties does not guarantee good antiviral activity without the proper orientations and distribution over the polysaccharide backbone.

A

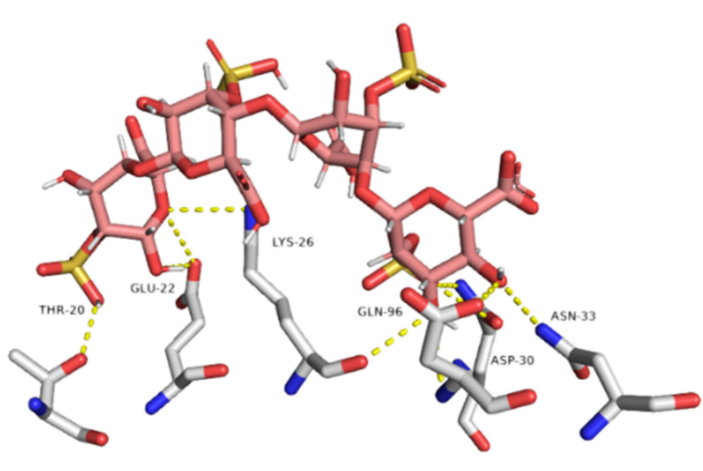

B

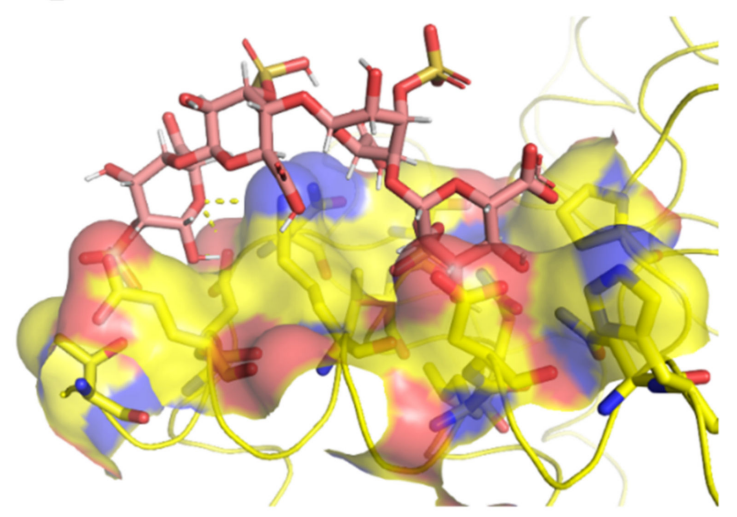

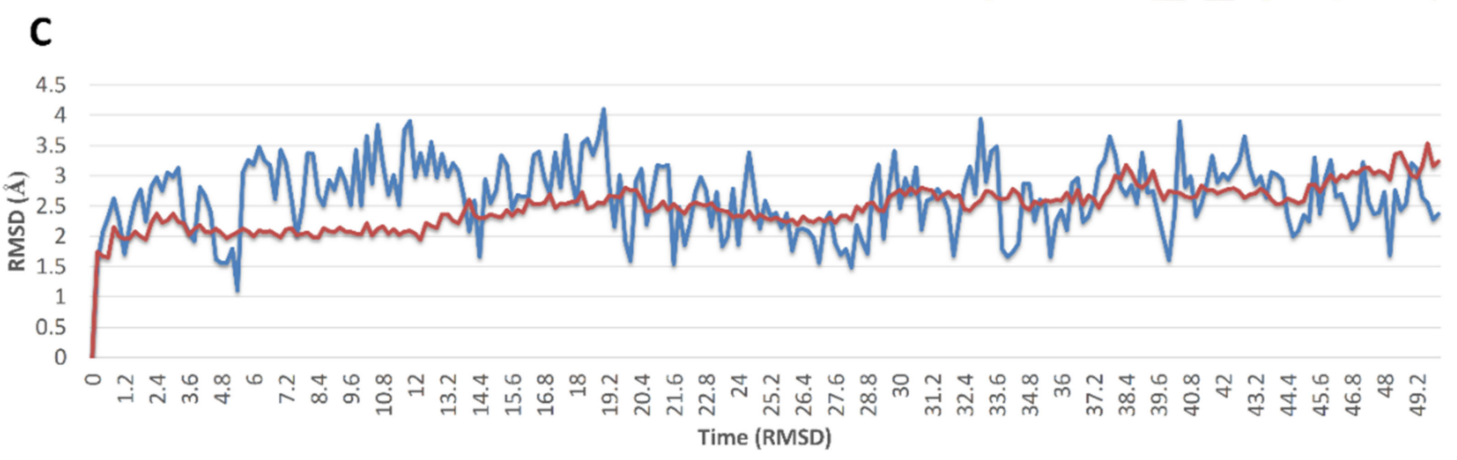

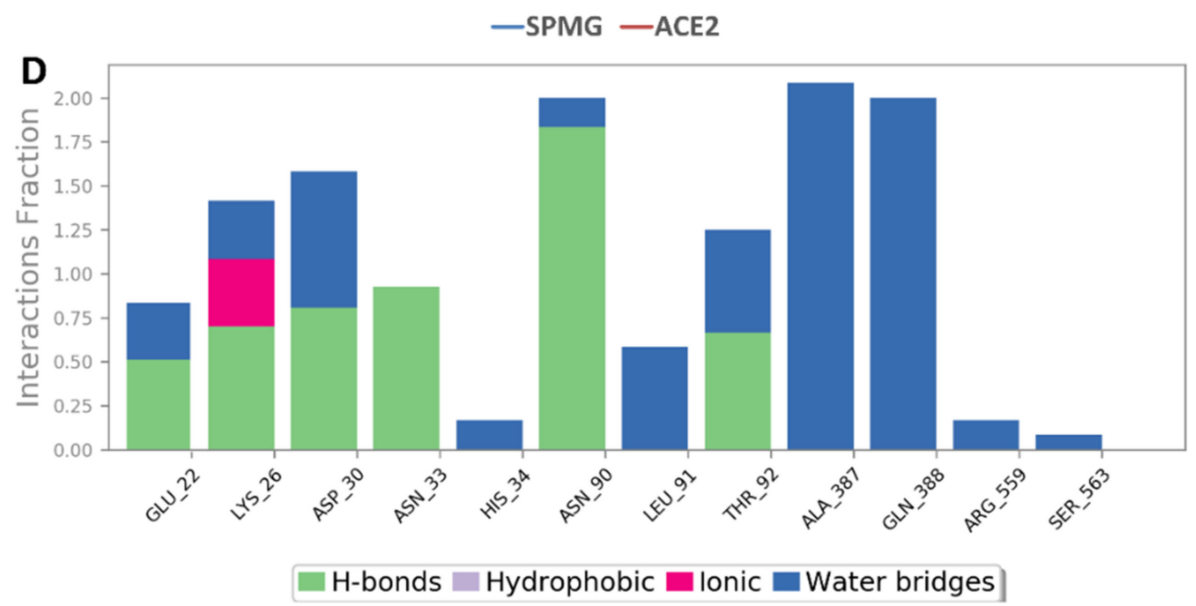

Figure 18. Binding mode of sulfated polymannuroguluronate (SPMG) (compound 2) inside site 3 (A,B) together with its RMSDs and protein-ligand contacts during 50 ns of MDSs (C,D). 
A

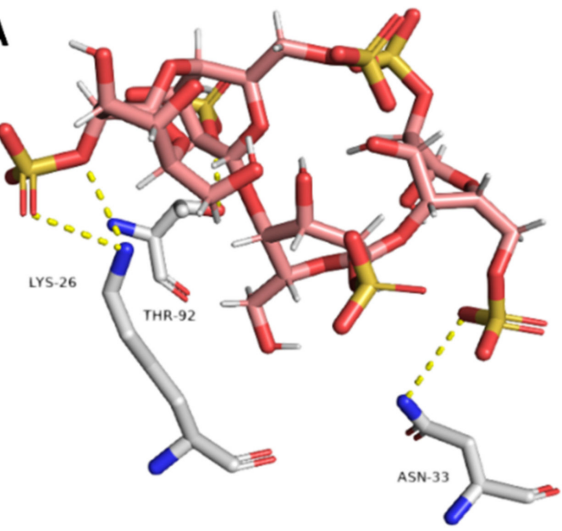

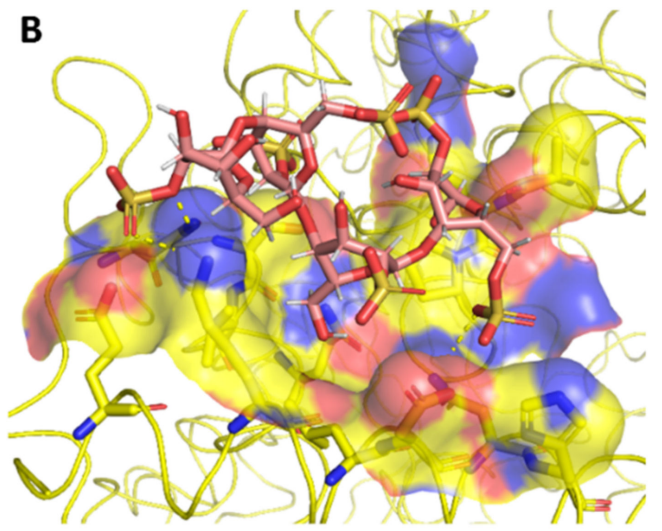
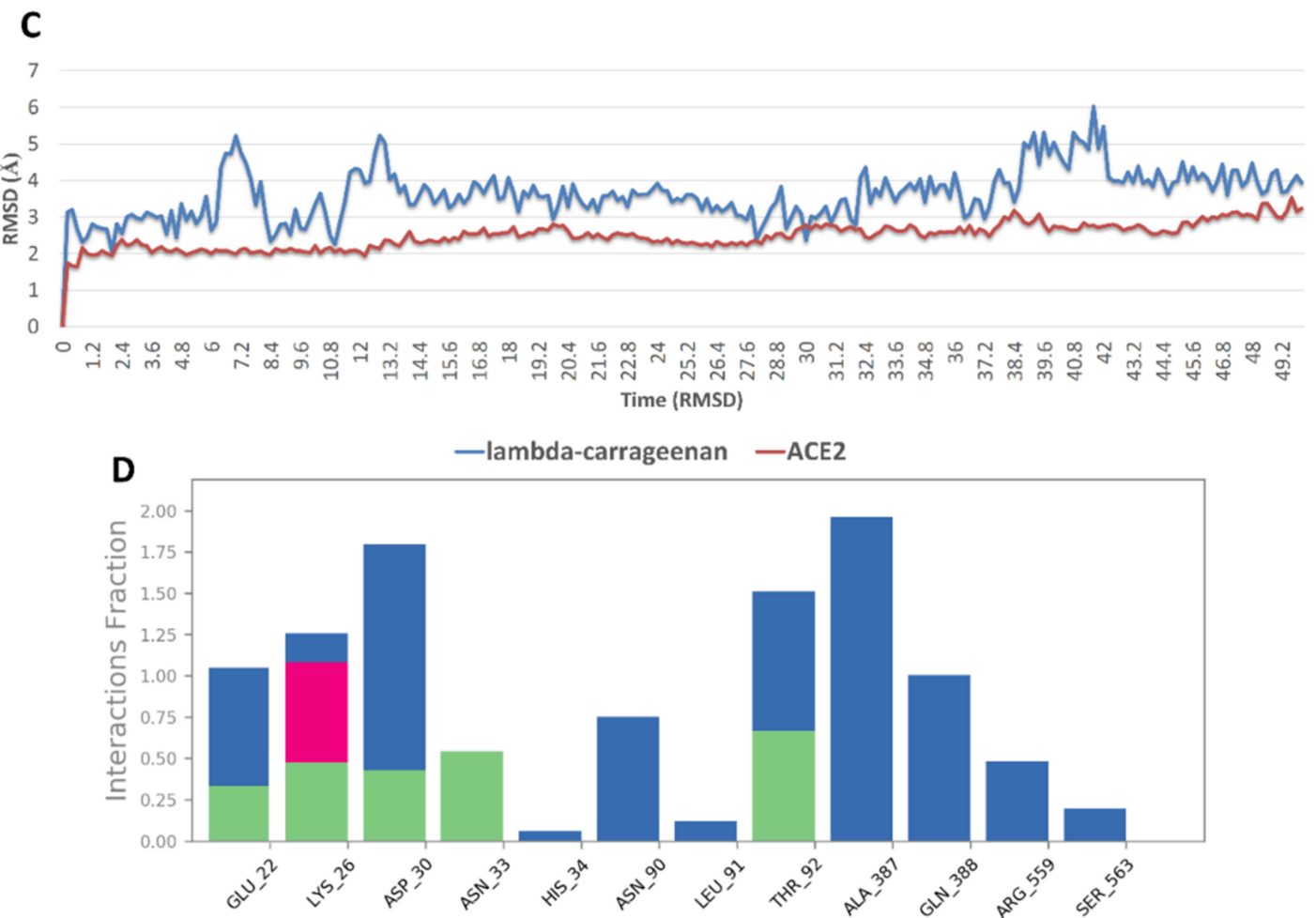

H-bonds Hydrophobic $\square$ Ionic $\square$ Water bridges

Figure 19. Binding mode of lambda-carrageenan (compound 5) inside site $3(\mathbf{A}, \mathbf{B})$ together with its RMSDs and proteinligand contacts during $50 \mathrm{~ns}$ of MDSs (C,D).

Finally, the general chemical structure of the polysaccharides (e.g., the stereochemistry of the glycosidic linkage and that of monosaccharides and the presence of branching points in the main backbone) has a general impact on the degree of their antiviral activity [111].

\section{Methodology}

\subsection{Databases Used}

The search for MSPs in this study was conducted using SciFinder (https:/ / www.cas. org/solutions / cas-scifinder-discovery-platform/cas-scifinder, accessed on 15 May 2021), Scopus (https:/ / www.scopus.com), Web of Science (https:/ / login.webofknowledge.com), Google Scholar, and DNP (Dictionary of Natural Products) databases. The keywords "antiviral", "SARS CoV-2", marine-derived", and "COVID-19" were paired with "sulphated polysaccharide" to obtain published records up until 2021. 


\subsection{Molecular Modeling}

We utilized the carbohydrate modeling protocol used by Sapay and his co-workers in our in silico study of MSPs [112].

\subsubsection{Molecular Docking}

The docking study was carried out against both the receptor-binding domain (RBD) of SARS CoV-2's spike protein (S-protein) and human angiotensin-converting enzyme-2 (ACE2) (PDB codes: 61ZG and 1R42, respectively) [113,114]. An Autodock Vina docking machine [105] was used for docking experiments. To determine the best binding site for docking, we docked heparin (i.e., sulphated poly saccharide analogue) against both S-protein and ACE2 using the ClusPro server [14] by uploading each crystal structure to the website and choosing heparin as a ligand. The retrieved docking poses were then arranged from the highest to the lowest scores. We selected the docking pose of the highest score and subjected it to a short molecular dynamic simulation $(25 \mathrm{~ns})$ experiment to study the stability of heparin in this pose. Heparin showed acceptable stability in this orientation, where it deviated from the initial pose by an average RMSD of $2.1 \AA$ (Figure 6); hence, the binding site of heparin in this pose was used for docking in the subsequent docking experiments. Heparin docking was carried out using its tetrasaccharide form (i.e., the default form in the ClusPro software). Accordingly, we also used the tetrasaccharide form of each MSP for docking experiments to reduce the computational cost required for docking and molecular dynamic simulations. All results were visualized using PyMol software [115].

\subsubsection{Molecular Dynamic Simulation}

MD simulation experiments were carried out using the MDS machine in Maestro software, Desmond v. 2. [116-118], using its default force field (i.e., OPLS-AA). Proteinligand systems were constructed using the System Builder function. Thereafter, these systems were embedded in an orthorhombic box consisting of TIP3P water and $0.15 \mathrm{M} \mathrm{Na}+$ and $\mathrm{Cl}$ - ions (the default dimensions were used). Subsequently, the prepared systems were energy-minimized and equilibrated for $10 \mathrm{~ns}$. Ligand parameterization was carried out during the system building step according to the OPLS force field. For MD simulations carried out using NAMD software, the parameters and topologies of the ligands were computed using the Charmm36 force field. The online software Ligand Reader and Modeler (http:/ / www.charmm-gui.org/?doc=input/ligandrm, accessed on 15 May 2021) [119] and the VMD plugin Force Field Toolkit (ffTK) [120] were utilized for this regard. The generated parameters and topology files were then loaded into VMD to read the proteinligand complexes without errors, then the simulation step was performed. MD simulations were run for $50 \mathrm{~ns}$ at $310 \mathrm{~K}$ in the NPT ensemble with the Nose-Hoover thermostat and Martyna-Tobias-Klein barostat using anisotropic coupling. We selected the best binding poses for each compound as starting co-ordinates to investigate their binding stability and mode of interaction.

\subsubsection{Binding Free Energy Calculations}

Binding free energy calculations $(\Delta G)$ were performed using the free energy perturbation (FEP) method [121]. Briefly, this method estimates the binding free energy (i.e., $\Delta G_{\text {binding }}$ ) according to the following equation: $\Delta G_{\text {binding }}=\Delta G_{\text {Complex }}-\Delta G_{\text {Ligand }}$. These estimations were derived from separate simulations (NAMD software was used for these experiments). All input files required for simulation by NAMD were papered using the online website Charmm-GUI (https:/ / charmm-gui.org/?doc=input/afes.abinding, accessed on 30 April 2021). Subsequently, we loaded these files into NAMD in order to produce the required simulations. The FEP function in NAMD was used to accomplish this experiment. The equilibration step was achieved in the NPT ensemble at $300 \mathrm{~K}$ and $1 \mathrm{~atm}(1.01325 \mathrm{bar})$ with Langevin piston pressure (for "complex" and "ligand") in the presence of the TIP3P water model. Then, $10 \mathrm{~ns}$ FEP simulations were carried out for each ligand and the last 
$5 \mathrm{~ns}$ of the free energy values was measured for the final free energy estimation [121]. All resulting trajectories were visualized and analyzed by VMD software.

\section{Conclusions}

To challenge highly virulent SARS CoV-2 and its emerging mutations, which have cost millions of lives, there is an urgent need to ramp up drug discovery pipelines within a short timeframe. In order to shorten the drug development cycle, screening of existing chemical libraries holds greater potential than starting from scratch. The levels of structural and functional diversity of MSPs have been widely discussed for their antiviral properties; however, the depth of these activities in terms of possible mechanisms against potential drug targets has been poorly studied. A large number of members belong to the class of SPs being overlooked as potential candidates to suppress the virulence of SARS CoV-2.

In the present investigation, we aimed to point out the most probable binding sites on S-protein's RBD and ACE2 using a well-known sulfated polysaccharide (i.e., heparin) as a molecular probe. Interestingly, the binding of heparin to these sites led to dissociation of the RBD-ACE2 complex. These MDS-derived results indicated and validated these proposed binding sites as potential targets for further ligands from the same chemical class. Accordingly, these identified binding sites were used in a series of docking experiments using most of the collected MSPs in this report. A number of MSPs were then found to be potential binders to these sites. Most of the identified hits have been reported to exert antiviral activity against SARS CoV-2; however, some of them have not, meaning they are considered very promising candidates for experimental testing. Overall, the present investigation shed light on the huge potential of MSPs as antiviral chemical entities and provided the scientific community hints about their potential against SARS CoV-2, with some important structural information to be utilized in further experimental research.

Supplementary Materials: The following are available online at https:/ / www.mdpi.com/article/10 $.3390 / \mathrm{md19080406/s1}$, Figure S1-S8 indicating details about the reported SMPs in addition to the reported SMPs that were reported in the manuscripts.

Author Contributions: Conceptualization, A.M.S., M.E.R.; methodology, A.E.M.S., B.T, A.S.I.H., A.M.S.; software, A.E.M.S., A.M.S.; validation, A.E.M.S., B.T., H.R.E.-S., A.M.S., M.Y., M.E.R.; formal analysis, A.E.M.S., A.M.S.; investigation, A.E.M.S., A.M.S., M.E.R.; data curation, B.T., M.Y., A.S.I.H., H.R.E.-S.., A.M.S., M.E.R.; writing—original draft preparation, A.E.M.S., A.M.S.; writing-review and editing, B.T., M.Y., H.R.E.-S., M.E.R.; supervision, M.E.R. All authors have read and agreed to the published version of the manuscript.

Funding: This research received no external funding.

Data Availability Statement: Not applicable.

Conflicts of Interest: The authors declare no conflict of interest.

\section{References}

1. Chen, L.; Huang, G. The antiviral activity of polysaccharides and their derivatives. Int. J. Biol. Macromol. 2018, 115, 77-82. [CrossRef] [PubMed]

2. Lee, S. Chapter 4-Strategic Design of Delivery Systems for Nutraceuticals. In Nanotechnology Applications in Food; Oprea, A.E., Grumezescu, A.M., Eds.; Academic Press: Cambridge, MA, USA, 2017; pp. 65-86. [CrossRef]

3. Ngo, D.-H.; Kim, S.-K. Sulfated polysaccharides as bioactive agents from marine algae. Int. J. Biol. Macromol. 2013, 62, 70-75. [CrossRef]

4. Hans, N.; Malik, A.; Naik, S. Antiviral activity of sulfated polysaccharides from marine algae and its application in combating COVID-19: Mini review. Bioresour. Technol. Rep. 2021, 13, 100623. [CrossRef] [PubMed]

5. Muthukumar, J.; Chidambaram, R.; Sukumaran, S. Sulfated polysaccharides and its commercial applications in food industries-A review. J. Food Sci. Technol. 2020. [CrossRef]

6. Koenighofer, M.; Lion, T.; Bodenteich, A.; Prieschl-Grassauer, E.; Grassauer, A.; Unger, H.; Mueller, C.A.; Fazekas, T. Carrageenan nasal spray in virus confirmed common cold: Individual patient data analysis of two randomized controlled trials. Multidiscip. Respir. Med. 2014, 9, 57. [CrossRef] [PubMed] 
7. Graf, C.; Bernkop-Schnürch, A.; Egyed, A.; Koller, C.; Prieschl-Grassauer, E.; Morokutti-Kurz, M. Development of a nasal spray containing xylometazoline hydrochloride and iota-carrageenan for the symptomatic relief of nasal congestion caused by rhinitis and sinusitis. Int. J. Gen. Med. 2018, 11, 275. [CrossRef]

8. Morokutti-Kurz, M.; Graf, C.; Prieschl-Grassauer, E. Amylmetacresol/2, 4-dichlorobenzyl alcohol, hexylresorcinol, or carrageenan lozenges as active treatments for sore throat. Int. J. Gen. Med. 2017, 10, 53. [CrossRef]

9. Ekins, S.; Mestres, J.; Testa, B. In silico pharmacology for drug discovery: Methods for virtual ligand screening and profiling. Br. J. Pharmacol. 2007, 152, 9-20. [CrossRef]

10. Sliwoski, G.; Kothiwale, S.; Meiler, J.; Lowe, E.W. Computational methods in drug discovery. Pharmacol. Rev. 2014, 66, 334-395. [CrossRef]

11. Makhouri, F.R.; Ghasemi, J.B. In Silico Studies in Drug Research Against Neurodegenerative Diseases. Curr. Neuropharmacol. 2018, 16, 664-725. [CrossRef] [PubMed]

12. Phillips, M.A. Has Molecular Docking Ever Brought Us a Medicine? IntechOpen: London, UK, 2018. [CrossRef]

13. Fadda, E.; Woods, R.J. Molecular simulations of carbohydrates and protein-carbohydrate interactions: Motivation, issues and prospects. Drug Discov. Today 2010, 15, 596-609. [CrossRef] [PubMed]

14. Hemmingson, J.A.; Falshaw, R.; Furneaux, R.H.; Thompson, K. Structure and Antiviral Activity of the Galactofucan Sulfates Extracted from UndariaPinnatifida (Phaeophyta). J. Appl. Phycol. 2006, 18, 185. [CrossRef]

15. Vishchuk, O.S.; Ermakova, S.P.; Zvyagintseva, T.N. Sulfated polysaccharides from brown seaweeds Saccharina japonica and Undaria pinnatifida: Isolation, structural characteristics, and antitumor activity. Carbohydr. Res. 2011, 346, 2769-2776. [CrossRef]

16. Mandal, P.; Mateu, C.G.; Chattopadhyay, K.; Pujol, C.A.; Damonte, E.B.; Ray, B. Structural Features and Antiviral Activity of Sulphated Fucans from the Brown Seaweed Cystoseira Indica. Antivir. Chem. Chemother. 2007, 18, 153-162. [CrossRef]

17. Kwon, P.S.; Oh, H.; Kwon, S.-J.; Jin, W.; Zhang, F.; Fraser, K.; Hong, J.J.; Linhardt, R.J.; Dordick, J.S. Sulfated polysaccharides effectively inhibit SARS-CoV-2 in vitro. Cell Discov. 2020, 6, 50. [CrossRef]

18. Song, S.; Peng, H.; Wang, Q.; Liu, Z.; Dong, X.; Wen, C.; Ai, C.; Zhang, Y.; Wang, Z.; Zhu, B. Inhibitory activities of marine sulfated polysaccharides against SARS-CoV-2. Food Funct. 2020, 11, 7415-7420. [CrossRef]

19. Usoltseva, R.V.; Anastyuk, S.D.; Ishina, I.A.; Isakov, V.V.; Zvyagintseva, T.N.; Thinh, P.D.; Zadorozhny, P.A.; Dmitrenok, P.S.; Ermakova, S.P. Structural characteristics and anticancer activity in vitro of fucoidan from brown alga Padina boryana. Carbohydr. Polym. 2018, 184, 260-268. [CrossRef] [PubMed]

20. Miao, B.; Geng, M.; Li, J.; Li, F.; Chen, H.; Guan, H.; Ding, J. Sulfated polymannuroguluronate, a novel anti-acquired immune deficiency syndrome (AIDS) drug candidate, targeting CD4 in lymphocytes. Biochem. Pharmacol. 2004, 68, 641-649. [CrossRef]

21. Meiyu, G.; Fuchuan, L.; Xianliang, X.; Jing, L.; Zuowei, Y.; Huashi, G. The potential molecular targets of marine sulfated polymannuroguluronate interfering with HIV-1 entry: Interaction between SPMG and HIV-1 rgp120 and CD4 molecule. Antivir. Res. 2003, 59, 127-135. [CrossRef]

22. Liu, H.; Geng, M.; Xin, X.; Li, F.; Zhang, Z.; Li, J.; Ding, J. Multiple and multivalent interactions of novel anti-AIDS drug candidates, sulfated polymannuronate (SPMG)-derived oligosaccharides, with gp120 and their anti-HIV activities. Glycobiology 2004, 15, 501-510. [CrossRef]

23. Ponce, N.M.A.; Pujol, C.A.; Damonte, E.B.; Flores, M.L.; Stortz, C.A. Fucoidans from the brown seaweed Adenocystis utricularis: Extraction methods, antiviral activity and structural studies. Carbohydr. Res. 2003, 338, 153-165. [CrossRef]

24. Ale, M.T.; Mikkelsen, J.D.; Meyer, A.S. Important Determinants for Fucoidan Bioactivity: A Critical Review of Structure-Function Relations and Extraction Methods for Fucose-Containing Sulfated Polysaccharides from Brown Seaweeds. Mar. Drugs 2011, 9 , 2106-2130. [CrossRef] [PubMed]

25. Adhikari, U.; Mateu, C.G.; Chattopadhyay, K.; Pujol, C.A.; Damonte, E.B.; Ray, B. Structure and antiviral activity of sulfated fucans from Stoechospermum marginatum. Phytochemistry 2006, 67, 2474-2482. [CrossRef] [PubMed]

26. Shen, P.; Yin, Z.; Qu, G.; Wang, C. 11-fucoidan and its health benefits. In Bioactive Seaweeds for Food Applications; Qin, Y., Ed.; Academic Press: Cambridge, MA, USA, 2018; pp. 223-238.

27. Hoshino, T.; Hayashi, T.; Hayashi, K.; Hamada, J.; Lee, J.-B.; Sankawa, U. An antivirally active sulfated polysaccharide from Sargassum horneri (TURNER) C. AGARDH. Biol. Pharm. Bull. 1998, 21, 730-734. [CrossRef]

28. Wang, W.; Wu, J.; Zhang, X.; Hao, C.; Zhao, X.; Jiao, G.; Shan, X.; Tai, W.; Yu, G. Inhibition of Influenza A Virus Infection by Fucoidan Targeting Viral Neuraminidase and Cellular EGFR Pathway. Sci. Rep. 2017, 7, 40760. [CrossRef] [PubMed]

29. Zhu, W.; Ooi, V.E.C.; Chan, P.K.S.; Ang, P.O., Jr. Isolation and characterization of a sulfated polysaccharide from the brown alga Sargassum patens and determination of its anti-herpes activity. Biochem. Cell Biol. 2003, 81, 25-33. [CrossRef] [PubMed]

30. Feldman, S.C.; Reynaldi, S.; Stortz, C.A.; Cerezo, A.S.; Damonte, E.B. Antiviral properties of fucoidan fractions from Leathesia difformis. Phytomedicine 1999, 6, 335-340. [CrossRef]

31. Krylova, N.V.; Ermakova, S.P.; Lavrov, V.F.; Leneva, I.A.; Kompanets, G.G.; Iunikhina, O.V.; Nosik, M.N.; Ebralidze, L.K.; Falynskova, I.N.; Silchenko, A.S.; et al. The Comparative Analysis of Antiviral Activity of Native and Modified Fucoidans from Brown Algae Fucus evanescens In Vitro and In Vivo. Mar. Drugs 2020, 18, 224. [CrossRef]

32. Lee, J.-B.; Hayashi, K.; Hashimoto, M.; Nakano, T.; Hayashi, T. Novel Antiviral Fucoidan from Sporophyll of Undaria pinnatifida (Mekabu). Chem. Pharm. Bull. 2004, 52, 1091-1094. [CrossRef] [PubMed]

33. Bandyopadhyay, S.S.; Navid, M.H.; Ghosh, T.; Schnitzler, P.; Ray, B. Structural features and in vitro antiviral activities of sulfated polysaccharides from Sphacelaria indica. Phytochemistry 2011, 72, 276-283. [CrossRef] 
34. Thuy, T.T.T.; Ly, B.M.; Van, T.T.T.; Van Quang, N.; Tu, H.C.; Zheng, Y.; Seguin-Devaux, C.; Mi, B.; Ai, U. Anti-HIV activity of fucoidans from three brown seaweed species. Carbohydr. Polym. 2015, 115, 122-128. [CrossRef]

35. Elizondo-Gonzalez, R.; Cruz-Suarez, L.E.; Ricque-Marie, D.; Mendoza-Gamboa, E.; Rodriguez-Padilla, C.; Trejo-Avila, L.M. In vitro characterization of the antiviral activity of fucoidan from Cladosiphon okamuranus against Newcastle Disease Virus. Virol. J. 2012, 9, 307. [CrossRef] [PubMed]

36. Hidari, K.I.P.J.; Takahashi, N.; Arihara, M.; Nagaoka, M.; Morita, K.; Suzuki, T. Structure and anti-dengue virus activity of sulfated polysaccharide from a marine alga. Biochem. Biophys. Res. Commun. 2008, 376, 91-95. [CrossRef] [PubMed]

37. Richards, C.; Williams, N.A.; Fitton, J.H.; Stringer, D.N.; Karpiniec, S.S.; Park, A.Y. Oral Fucoidan Attenuates Lung Pathology and Clinical Signs in a Severe Influenza a Mouse Model. Mar. Drugs 2020, 18, 246. [CrossRef]

38. Synytsya, A.; Bleha, R.; Synytsya, A.; Pohl, R.; Hayashi, K.; Yoshinaga, K.; Nakano, T.; Hayashi, T. Mekabu fucoidan: Structural complexity and defensive effects against avian influenza A viruses. Carbohydr. Polym. 2014, 111, 633-644. [CrossRef]

39. Talarico, L.B.; Zibetti, R.G.M.; Faria, P.C.S.; Scolaro, L.A.; Duarte, M.E.R.; Noseda, M.D.; Pujol, C.A.; Damonte, E.B. Anti-herpes simplex virus activity of sulfated galactans from the red seaweeds Gymnogongrus griffithsiae and Cryptonemia crenulata. Int. J. Biol. Macromol. 2004, 34, 63-71. [CrossRef] [PubMed]

40. Ghosh, T.; Pujol, C.A.; Damonte, E.B.; Sinha, S.; Ray, B. Sulfated Xylomannans from the Red Seaweed Sebdenia Polydactyla: Structural Features, Chemical Modification and Antiviral Activity. Antivir. Chem. Chemother. 2009, 19, 235-242. [CrossRef]

41. Morokutti-Kurz, M.; Fröba, M.; Graf, P.; Große, M.; Grassauer, A.; Auth, J.; Schubert, U.; Prieschl-Grassauer, E. Iota-carrageenan neutralizes SARS-CoV-2 and inhibits viral replication in vitro. PLoS ONE 2021, 16, e0237480. [CrossRef] [PubMed]

42. Hongu, T.; Phillips, G.O.; Takigami, M. 7-Polymer fibers for health and nutrition. In New Millennium Fibers; Hongu, T., Phillips, G.O., Takigami, M., Eds.; Woodhead Publishing: Sawston, UK, 2005; pp. 218-246.

43. Bansal, S.; Jonsson, C.B.; Taylor, S.L.; Figueroa, J.M.; Dugour, A.V.; Palacios, C.; César Vega, J. Iota-carrageenan and Xylitol inhibit SARS-CoV-2 in cell culture. bioRxiv 2020. [CrossRef]

44. Jang, Y.; Shin, H.; Lee, M.K.; Kwon, O.S.; Shin, J.S.; Kim, Y.; Kim, M. Antiviral activity of lambda-carrageenan against influenza viruses in mice and severe acute respiratory syndrome coronavirus 2 in vitro. bioRxiv 2020. [CrossRef]

45. Carlucci, M.J.; Ciancia, M.; Matulewicz, M.C.; Cerezo, A.S.; Damonte, E.B. Antiherpetic activity and mode of action of natural carrageenans of diverse structural types. Antivir. Res. 1999, 43, 93-102. [CrossRef]

46. Chattopadhyay, K.; Ghosh, T.; Pujol, C.A.; Carlucci, M.J.; Damonte, E.B.; Ray, B. Polysaccharides from Gracilaria corticata: Sulfation, chemical characterization and anti-HSV activities. Int. J. Biol. Macromol. 2008, 43, 346-351. [CrossRef] [PubMed]

47. Pujol, C.A.; Estevez, J.M.; Carlucci, M.J.; Ciancia, M.; Cerezo, A.S.; Damonte, E.B. Novel DL-Galactan Hybrids from the Red Seaweed Gymnogongrus Torulosus are Potent Inhibitors of Herpes Simplex Virus and Dengue Virus. Antivir. Chem. Chemother. 2002, 13, 83-89. [CrossRef]

48. Kang, H.-K.; Seo, C.; Park, Y. The Effects of Marine Carbohydrates and Glycosylated Compounds on Human Health. Int. J. Mol. Sci. 2015, 16, 6018-6056. [CrossRef]

49. Talarico, L.B.; Pujol, C.A.; Zibetti, R.G.M.; Faría, P.C.S.; Noseda, M.D.; Duarte, M.E.R.; Damonte, E.B. The antiviral activity of sulfated polysaccharides against dengue virus is dependent on virus serotype and host cell. Antivir. Res. 2005, 66, 103-110. [CrossRef] [PubMed]

50. Cáceres, P.J.; Carlucci, M.a.J.; Damonte, E.B.; Matsuhiro, B.; Zúñiga, E.A. Carrageenans from chilean samples of Stenogramme interrupta (Phyllophoraceae): Structural analysis and biological activity. Phytochemistry 2000, 53, 81-86. [CrossRef]

51. Mazumder, S.; Ghosal, P.K.; Pujol, C.A.; Carlucci, M.a.J.; Damonte, E.B.; Ray, B. Isolation, chemical investigation and antiviral activity of polysaccharides from Gracilaria corticata (Gracilariaceae, Rhodophyta). Int. J. Biol. Macromol. 2002, 31, 87-95. [CrossRef]

52. Pereira, M.G.; Benevides, N.M.B.; Melo, M.R.S.; Valente, A.P.; Melo, F.R.; Mourão, P.A.S. Structure and anticoagulant activity of a sulfated galactan from the red alga, Gelidium crinale. Is there a specific structural requirement for the anticoagulant action? Carbohydr. Res. 2005, 340, 2015-2023. [CrossRef]

53. Witvrouw, M.; Este, J.A.; Mateu, M.Q.; Reymen, D.; Andrei, G.; Snoeck, R.; Ikeda, S.; Pauwels, R.; Bianchini, N.V.; Desmyter, J.; et al. Activity of a Sulfated Polysaccharide Extracted from the Red Seaweed Aghardhiella Tenera against Human Immunodeficiency Virus and Other Enveloped Viruses. Antivir. Chem. Chemother. 1994, 5, 297-303. [CrossRef]

54. Pérez Recalde, M.; Noseda, M.D.; Pujol, C.A.; Carlucci, M.J.; Matulewicz, M.C. Sulfated mannans from the red seaweed Nemalion helminthoides of the South Atlantic. Phytochemistry 2009, 70, 1062-1068. [CrossRef]

55. Kolender, A.A.; Pujol, C.A.; Damonte, E.B.; Matulewicz, M.C.; Cerezo, A.S. The system of sulfated $\alpha-(1 \rightarrow 3)-$ linked D-mannans from the red seaweed Nothogenia fastigiata: Structures, antiherpetic and anticoagulant properties. Carbohydr. Res. 1997, 304, 53-60. [CrossRef]

56. Erra-Balsells, R.; Kolender, A.A.; Matulewicz, M.a.C.; Nonami, H.; Cerezo, A.S. Matrix-assisted ultraviolet laser-desorption ionization time-of-flight mass spectrometry of sulfated mannans from the red seaweed Nothogenia fastigiata. Carbohydr. Res. 2000, 329, 157-167. [CrossRef]

57. Mandal, P.; Pujol, C.A.; Carlucci, M.J.; Chattopadhyay, K.; Damonte, E.B.; Ray, B. Anti-herpetic activity of a sulfated xylomannan from Scinaia hatei. Phytochemistry 2008, 69, 2193-2199. [CrossRef]

58. Damonte, E.B.; Matulewicz, M.C.; Cerezob, A.S.; Coto, C.E. Herpes simplex Virus-Inhibitory Sulfated Xylogalactans from the Red Seaweed Nothogenia fastigiata. Chemotherapy 1996, 42, 57-64. [CrossRef] 
59. Navarro, D.A.; Stortz, C.A. The system of xylogalactans from the red seaweed Jania rubens (Corallinales, Rhodophyta). Carbohydr. Res. 2008, 343, 2613-2622. [CrossRef]

60. Talarico, L.B.; Damonte, E.B. Interference in dengue virus adsorption and uncoating by carrageenans. Virology 2007, 363, 473-485. [CrossRef]

61. Hemilä, H.; Chalker, E. Carrageenan nasal spray may double the rate of recovery from coronavirus and influenza virus infections: Re-analysis of randomized trial data. Res. Sq. 2020. [CrossRef]

62. Leibbrandt, A.; Meier, C.; König-Schuster, M.; Weinmüllner, R.; Kalthoff, D.; Pflugfelder, B.; Graf, P.; Frank-Gehrke, B.; Beer, M.; Fazekas, T. Iota-carrageenan is a potent inhibitor of influenza A virus infection. PLoS ONE 2010, 5, e14320. [CrossRef] [PubMed]

63. Grassauer, A.; Weinmuellner, R.; Meier, C.; Pretsch, A.; Prieschl-Grassauer, E.; Unger, H. Iota-Carrageenan is a potent inhibitor of rhinovirus infection. Virol. J. 2008, 5, 107. [CrossRef]

64. Buck, C.B.; Thompson, C.D.; Roberts, J.N.; Müller, M.; Lowy, D.R.; Schiller, J.T. Carrageenan is a potent inhibitor of papillomavirus infection. PLoS Pathog 2006, 2, e69. [CrossRef] [PubMed]

65. Gomaa, H.H.; Elshoubaky, G.A. Antiviral activity of sulfated polysaccharides carrageenan from some marine seaweeds. Int. J. Curr. Pharm. Rev. Res. 2016, 7, 34-42.

66. Malagoli, B.G.; Cardozo, F.T.G.S.; Gomes, J.H.S.; Ferraz, V.P.; Simões, C.M.O.; Braga, F.C. Chemical characterization and antiherpes activity of sulfated polysaccharides from Lithothamnion muelleri. Int. J. Biol. Macromol. 2014, 66, 332-337. [CrossRef] [PubMed]

67. Mandal, P.; Pujol, C.A.; Damonte, E.B.; Ghosh, T.; Ray, B. Xylans from Scinaia hatei: Structural features, sulfation and anti-HSV activity. Int. J. Biol. Macromol. 2010, 46, 173-178. [CrossRef] [PubMed]

68. Nor Rashid, N.; Yusof, R.; Rothan, H.A. Antiviral and virucidal activities of sulphated polysaccharides against Japanese encephalitis virus. Trop. Biomed. 2020, 37, 713-721. [CrossRef] [PubMed]

69. Reunov, A.; Nagorskaya, V.; Lapshina, L.; Yermak, I.; Barabanova, A. Effect of k/ß-Carrageenan from red alga Tichocarpus crinitus (Tichocarpaceae) on infection of detached tobacco leaves with tobacco mosaic virus. J. Plant Dis. Prot. 2004, 111, 165-172. [CrossRef]

70. Piccini, L.E.; Carro, A.C.; Quintana, V.M.; Damonte, E.B. Antibody-independent and dependent infection of human myeloid cells with dengue virus is inhibited by carrageenan. Virus Res. 2020, 290, 198150. [CrossRef] [PubMed]

71. De S.F-Ticher, P.C.; Talarico, L.B.; Noseda, M.D.; Pita, B.; Guimarães, S.M.; Damonte, E.B.; Duarte, M.E.R. Chemical structure and antiviral activity of carrageenans from Meristiella gelidium against herpes simplex and dengue virus. Carbohydr. Polym. 2006, 63, 459-465. [CrossRef]

72. Girond, S.; Crance, J.M.; Van Cuyck-Gandre, H.; Renaudet, J.; Deloince, R. Antiviral activity of carrageenan on hepatitis A virus replication in cell culture. Res. Virol. 1991, 142, 261-270. [CrossRef]

73. Bouhlal, R.; Haslin, C.; Chermann, J.-C.; Colliec-Jouault, S.; Sinquin, C.; Simon, G.; Cerantola, S.; Riadi, H.; Bourgougnon, N. Antiviral Activities of Sulfated Polysaccharides Isolated from Sphaerococcus coronopifolius (Rhodophytha, Gigartinales) and Boergeseniella thuyoides (Rhodophyta, Ceramiales). Mar. Drugs 2011, 9, 1187-1209. [CrossRef]

74. Lopes, N.; Ray, S.; Espada, S.F.; Bomfim, W.A.; Ray, B.; Faccin-Galhardi, L.C.; Linhares, R.E.C.; Nozawa, C. Green seaweed Enteromorpha compressa (Chlorophyta, Ulvaceae) derived sulphated polysaccharides inhibit herpes simplex virus. Int. J. Biol. Macromol. 2017, 102, 605-612. [CrossRef]

75. Robic, A.; Rondeau-Mouro, C.; Sassi, J.F.; Lerat, Y.; Lahaye, M. Structure and interactions of ulvan in the cell wall of the marine green algae Ulva rotundata (Ulvales, Chlorophyceae). Carbohydr. Polym. 2009, 77, 206-216. [CrossRef]

76. Wang, S.; Wang, W.; Hao, C.; Yunjia, Y.; Qin, L.; He, M.; Mao, W. Antiviral activity against enterovirus 71 of sulfated rhamnan isolated from the green alga Monostroma latissimum. Carbohydr. Polym. 2018, 200, 43-53. [CrossRef] [PubMed]

77. Morán-Santibañez, K.; Cruz-Suárez, L.E.; Ricque-Marie, D.; Robledo, D.; Freile-Pelegrín, Y.; Peña-Hernández, M.A.; RodríguezPadilla, C.; Trejo-Avila, L.M. Synergistic Effects of Sulfated Polysaccharides from Mexican Seaweeds against Measles Virus. BioMed Res. Int. 2016, 2016, 8502123. [CrossRef]

78. Aguilar-Briseño, J.A.; Cruz-Suarez, L.E.; Sassi, J.-F.; Ricque-Marie, D.; Zapata-Benavides, P.; Mendoza-Gamboa, E.; RodríguezPadilla, C.; Trejo-Avila, L.M. Sulphated Polysaccharides from Ulva clathrata and Cladosiphon okamuranus Seaweeds both Inhibit Viral Attachment/Entry and Cell-Cell Fusion, in NDV Infection. Mar. Drugs 2015, 13, 697-712. [CrossRef] [PubMed]

79. Hardouin, K.; Bedoux, G.; Burlot, A.-S.; Donnay-Moreno, C.; Bergé, J.-P.; Nyvall-Collén, P.; Bourgougnon, N. Enzyme-assisted extraction (EAE) for the production of antiviral and antioxidant extracts from the green seaweed Ulva armoricana (Ulvales, Ulvophyceae). Algal Res. 2016, 16, 233-239. [CrossRef]

80. Terasawa, M.; Hayashi, K.; Lee, J.-B.; Nishiura, K.; Matsuda, K.; Hayashi, T.; Kawahara, T. Anti-Influenza A Virus Activity of Rhamnan Sulfate from Green Algae Monostroma nitidum in Mice with Normal and Compromised Immunity. Mar. Drugs 2020, 18, 254. [CrossRef] [PubMed]

81. Lee, J.-B.; Koizumi, S.; Hayashi, K.; Hayashi, T. Structure of rhamnan sulfate from the green alga Monostroma nitidum and its anti-herpetic effect. Carbohydr. Polym. 2010, 81, 572-577. [CrossRef]

82. Cassolato, J.E.F.; Noseda, M.D.; Pujol, C.A.; Pellizzari, F.M.; Damonte, E.B.; Duarte, M.E.R. Chemical structure and antiviral activity of the sulfated heterorhamnan isolated from the green seaweed Gayralia oxysperma. Carbohydr. Res. 2008, 343, 3085-3095. [CrossRef] [PubMed]

83. Ohta, Y.; Lee, J.-B.; Hayashi, K.; Hayashi, T. Isolation of Sulfated Galactan from Codium fragile and Its Antiviral Effect. Biol. Pharm. Bull. 2009, 32, 892-898. [CrossRef] 
84. Lee, J.B.; Hayashi, K.; Maeda, M.; Hayashi, T. Antiherpetic activities of sulfated polysaccharides from green algae. Planta Med 2004, 70, 813-817. [CrossRef]

85. Chiu, Y.-H.; Chan, Y.-L.; Li, T.-L.; Wu, C.-J. Inhibition of Japanese Encephalitis Virus Infection by the Sulfated Polysaccharide Extracts from Ulva lactuca. Mar. Biotechnol. 2012, 14, 468-478. [CrossRef]

86. Song, L.; Chen, X.; Liu, X.; Zhang, F.; Hu, L.; Yue, Y.; Li, K.; Li, P. Characterization and Comparison of the Structural Features, Immune-Modulatory and Anti-Avian Influenza Virus Activities Conferred by Three Algal Sulfated Polysaccharides. Mar. Drugs 2015, 14, 4. [CrossRef]

87. Pujol, C.A.; Ray, S.; Ray, B.; Damonte, E.B. Antiviral activity against dengue virus of diverse classes of algal sulfated polysaccharides. Int. J. Biol. Macromol. 2012, 51, 412-416. [CrossRef] [PubMed]

88. Hayashi, T.; Hayashi, K.; Maeda, M.; Kojima, I. Calcium Spirulan, an Inhibitor of Enveloped Virus Replication, from a Blue-Green Alga Spirulina platensis. J. Nat. Prod. 1996, 59, 83-87. [CrossRef] [PubMed]

89. Lee, J.-B.; Srisomporn, P.; Hayashi, K.; Tanaka, T.; Sankawa, U.; Hayashi, T. Effects of Structural Modification of Calcium Spirulan, a Sulfated Polysaccharide from Spirulina Platensis, on Antiviral Activity. Chem. Pharm. Bull. 2001, 49, 108-110. [CrossRef]

90. Mader, J.; Gallo, A.; Schommartz, T.; Handke, W.; Nagel, C.-H.; Günther, P.; Brune, W.; Reich, K. Calcium spirulan derived from Spirulina platensis inhibits herpes simplex virus 1 attachment to human keratinocytes and protects against herpes labialis. J. Allergy Clin. Immunol. 2016, 137, 197-203. [CrossRef] [PubMed]

91. Ogura, F.; Hayashi, K.; Lee, J.-B.; Kanekiyo, K.; Hayashi, T. Evaluation of an Edible Blue-Green Alga, Aphanothece sacrum, for Its Inhibitory Effect on Replication of Herpes Simplex Virus Type 2 and Influenza Virus Type A. Biosci. Biotechnol. Biochem. 2010, 74, 1687-1690. [CrossRef]

92. Hernández-Corona, A.; Nieves, I.; Meckes, M.; Chamorro, G.; Barron, B.L. Antiviral activity of Spirulina maxima against herpes simplex virus type 2. Antivir. Res. 2002, 56, 279-285. [CrossRef]

93. Huleihel, M.; Ishanu, V.; Tal, J.; Arad, S. Antiviral effect of red microalgal polysaccharides on Herpes simplex and Varicella zoster viruses. J. Appl. Phycol. 2001, 13, 127-134. [CrossRef]

94. Lee, J.-B.; Hayashi, K.; Hirata, M.; Kuroda, E.; Suzuki, E.; Kubo, Y.; Hayashi, T. Antiviral Sulfated Polysaccharide from Navicula directa, a Diatom Collected from Deep-Sea Water in Toyama Bay. Biol. Pharm. Bull. 2006, 29, 2135-2139. [CrossRef]

95. Kim, M.; Yim, J.H.; Kim, S.-Y.; Kim, H.S.; Lee, W.G.; Kim, S.J.; Kang, P.-S.; Lee, C.-K. In vitro inhibition of influenza A virus infection by marine microalga-derived sulfated polysaccharide p-KG03. Antivir. Res. 2012, 93, 253-259. [CrossRef]

96. Yim, J.H.; Kim, S.J.; Ahn, S.H.; Lee, C.K.; Rhie, K.T.; Lee, H.K. Antiviral Effects of Sulfated Exopolysaccharide from the Marine Microalga Gyrodinium impudicum Strain KG03. Mar. Biotechnol. 2004, 6, 17-25. [CrossRef]

97. Hasui, M.; Matsuda, M.; Okutani, K.; Shigeta, S. In vitro antiviral activities of sulfated polysaccharides from a marine microalga (Cochlodinium polykrikoides) against human immunodeficiency virus and other enveloped viruses. Int. J. Biol. Macromol. 1995, 17, 293-297. [CrossRef]

98. Huang, N.; Wu, M.-Y.; Zheng, C.-B.; Zhu, L.; Zhao, J.-H.; Zheng, Y.-T. The depolymerized fucosylated chondroitin sulfate from sea cucumber potently inhibits HIV replication via interfering with virus entry. Carbohydr. Res. 2013, 380, 64-69. [CrossRef] [PubMed]

99. Kato, D.; Era, S.; Watanabe, I.; Arihara, M.; Sugiura, N.; Kimata, K.; Suzuki, Y.; Morita, K.; Hidari, K.I.P.J.; Suzuki, T. Antiviral activity of chondroitin sulphate E targeting dengue virus envelope protein. Antivir. Res. 2010, 88, 236-243. [CrossRef] [PubMed]

100. Bergefall, K.; Trybala, E.; Johansson, M.; Uyama, T.; Naito, S.; Yamada, S.; Kitagawa, H.; Sugahara, K.; Bergström, T. Chondroitin sulfate characterized by the E-disaccharide unit is a potent inhibitor of herpes simplex virus infectivity and provides the virus binding sites on gro2C cells. J. Biol. Chem. 2005, 280, 32193-32199. [CrossRef]

101. Perino, A.; Consiglio, P.; Maranto, M.; De Franciscis, P.; Marci, R.; Restivo, V.; Manzone, M.; Capra, G.; Cucinella, G.; Calagna, G. Impact of a new carrageenan-based vaginal microbicide in a female population with genital HPV-infection: First experimental results. Eur. Rev. Med. Pharm. Sci. 2019, 23, 6744-6752. [CrossRef]

102. Damonte, E.B.; Matulewicz, M.C.; Cerezo, A.S. Sulfated seaweed polysaccharides as antiviral agents. Curr. Med. Chem. 2004, 11, 2399-2419. [CrossRef] [PubMed]

103. Clausen, T.M.; Sandoval, D.R.; Spliid, C.B.; Pihl, J.; Perrett, H.R.; Painter, C.D.; Narayanan, A.; Majowicz, S.A.; Kwong, E.M.; McVicar, R.N.; et al. SARS-CoV-2 Infection Depends on Cellular Heparan Sulfate and ACE2. Cell 2020, 183, 1043-1057. [CrossRef]

104. Walls, A.C.; Park, Y.J.; Tortorici, M.A.; Wall, A.; McGuire, A.T.; Veesler, D. Structure, Function, and Antigenicity of the SARS-CoV-2 Spike Glycoprotein. Cell 2020, 181, 281-292. [CrossRef]

105. Mottarella, S.E.; Beglov, D.; Beglova, N.; Nugent, M.A.; Kozakov, D.; Vajda, S. Docking server for the identification of heparin binding sites on proteins. J. Chem. Inf. Model 2014, 54, 2068-2078. [CrossRef]

106. Singh, J.; Samal, J.; Kumar, V.; Sharma, J.; Agrawal, U.; Ehtesham, N.Z.; Sundar, D.; Rahman, S.A.; Hira, S.; Hasnain, S.E. Structure-Function Analyses of New SARS-CoV-2 Variants B.1.1.7, B.1.351 and B.1.1.28.1: Clinical, Diagnostic, Therapeutic and Public Health Implications. Viruses 2021, 13, 439. [CrossRef]

107. Witvrouw, M.; De Clercq, E. Sulfated polysaccharides extracted from sea algae as potential antiviral drugs. Gen. Pharm. 1997, 29, 497-511. [CrossRef]

108. Mukherjee, S.; Ghosh, K.; Hahn, F.; Wangen, C.; Strojan, H.; Müller, R.; Anand, N.; Ali, I.; Bera, K.; Ray, B.; et al. Chemically sulfated polysaccharides from natural sources: Assessment of extraction-sulfation efficiencies, structural features and antiviral activities. Int. J. Biol. Macromol. 2019, 136, 521-530. [CrossRef] [PubMed] 
109. Carlucci, M.J.; Scolaro, L.A.; Errea, M.I.; Matulewicz, M.C.; Damonte, E.B. Antiviral activity of natural sulphated galactans on herpes virus multiplication in cell culture. Planta Med. 1997, 63, 429-432. [CrossRef]

110. Rodríguez, M.C.; Merino, E.R.; Pujol, C.A.; Damonte, E.B.; Cerezo, A.S.; Matulewicz, M.C. Galactans from cystocarpic plants of the red seaweed Callophyllis variegata (Kallymeniaceae, Gigartinales). Carbohydr. Res. 2005, 340, 2742-2751. [CrossRef] [PubMed]

111. Jiao, G.; Yu, G.; Zhang, J.; Ewart, H.S. Chemical structures and bioactivities of sulfated polysaccharides from marine algae. Mar. Drugs 2011, 9, 196-223. [CrossRef]

112. Sapay, N.; Nurisso, A.; Imberty, A. Simulation of carbohydrates, from molecular docking to dynamics in water. Methods Mol. Biol. 2013, 924, 469-483. [CrossRef] [PubMed]

113. Wang, Q.; Zhang, Y.; Wu, L.; Niu, S.; Song, C.; Zhang, Z.; Lu, G.; Qiao, C.; Hu, Y.; Yuen, K.-Y.; et al. Structural and Functional Basis of SARS-CoV-2 Entry by Using Human ACE2. Cell 2020, 181, 894-904. [CrossRef] [PubMed]

114. Towler, P.; Staker, B.; Prasad, S.G.; Menon, S.; Tang, J.; Parsons, T.; Ryan, D.; Fisher, M.; Williams, D.; Dales, N.A.; et al. ACE2 $\mathrm{X}$-ray structures reveal a large hinge-bending motion important for inhibitor binding and catalysis. J. Biol. Chem. 2004, 279, 17996-18007. [CrossRef]

115. Seeliger, D.; De Groot, B.L. Ligand docking and binding site analysis with PyMOL and Autodock/Vina. J. Comput. Aided Mol. Des. 2010, 24, 417-422. [CrossRef]

116. Bowers, K.J.; Chow, D.E.; Xu, H.; Dror, R.O.; Eastwood, M.P.; Gregersen, B.A.; Klepeis, J.L.; Kolossvary, I.; Moraes, M.A.; Sacerdoti, F.D. Scalable algorithms for molecular dynamics simulations on commodity clusters. In Proceedings of the SC'06: 2006 ACM/IEEE Conference on Supercomputing, Tampa, FL, USA, 11-17 November 2006; p. 43.

117. Horner-Miller, B. CellSs: A programming model for the cell BE architecture. In Proceedings of the 2006 ACM/IEEE Conference on Supercomputing, Tampa, FL, USA, 11-17 November 2006; Association for Computing Machinery: New York, NY, USA, 2006.

118. Schrodinger Maestro; LLC: New York, NY, USA, 2009. Available online: https://www.schrodinger.com/products/maestro (accessed on 18 July 2021).

119. Jo, S.; Kim, T.; Iyer, V.G.; Im, W. CHARMM-GUI: A web-based graphical user interface for CHARMM. J. Comput. Chem. 2008, 29, 1859-1865. [CrossRef] [PubMed]

120. Humphrey, W.; Dalke, A.; Schulten, K. VMD: Visual molecular dynamics. J. Mol. Graph. 1996, 14, 33-38. [CrossRef]

121. Kim, S.; Oshima, H.; Zhang, H.; Kern, N.R.; Re, S.; Lee, J.; Roux, B.; Sugita, Y.; Jiang, W.; Im, W. CHARMM-GUI Free Energy Calculator for Absolute and Relative Ligand Solvation and Binding Free Energy Simulations. J. Chem. Theory Comput. 2020, 16, 7207-7218. [CrossRef] [PubMed] 